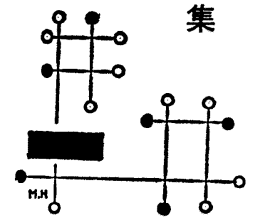

録

夕

1.ま え がき

タンタルはまだ実用面での歴史は浅いが，他の金属に 見られない数々の勝れた性質を持つているので，今後資 源に拈いても用途に打いてもますます開発される金属で あるといえよう(1)〜(5). タンタル Ta (英 Tantalum, 仏 tantale, 独 Tantal, 露 TaнTa , 中鉏) は天然には常 にニオブ $(\mathrm{Nb})$ と共存している元素である.

Ta は周期律表の位置からも推定されるよ5に Nbに 非常によく類似している、Va 族に属し勝れた耐食性を 示し，展延性に富んでいる．また第 3 長周期の元素でW に続く位置にあつて, 重く融点が高いことも特徵で一見 してやや青味がかつた銀白色を呈している.

$\mathrm{T} a$ の発見は, 古く 1802 年にスエーデンの化学者 A. G.Ekebergによりなされ, 当時この酸化物の 分解が極 めて困難であつたので, ギリシャ神話中の Tantalus に ちなんで名付けられた。 19 世紀のはじめごろは Ta と $\mathrm{Nb}(\mathrm{Cb})$ の分離が出来ていなかつたので混同されていた 模様であつたが，1844 年 H. Roseによりそれぞれ別 の元素であることが認められ，ついで 1866 年に J.C. Marignacによつて $\mathrm{Ta}$ と $\mathrm{Nb}$ の弗化カリ錯塩の溶解度 の相違を利用して分離確認がなされた.

$\mathrm{T} a$ 金属として商業規模の 製造は 1922 年にアメリカ ではじめられ，その非常に勝れた耐食性と高融点が認識 されて広く今日の工業的応用へ発展し, 近年に電子工業 への有用性も認められるよ5になつた。

\section{2. 盗源}

Ta のクラーク数は 44 で産出量も少ない金属である. 主要な鉱石 ${ }^{(6)}$ はタンタル石 (Tantalite) で化学組成は,

* 金属材料技術研究所; 非鉄金属材料研究部長

** 金属材料技術研究所; 非鉄金属材料研究部希有金 属研究室長

(1) C. A. Hampel : Rare Metals Hand book, 2 nd Ed., 469 518 (1961).

(2) F. T. Sisco and E. Epremian: Columbium and Tantalum, Jon Wiley and Sons, (1962).

(3) G. L. Miller : Tantalum and Niobium, Butter morths Sci., Publ., (1959).

（4）增田, 中山：金属学会会報, 2(1963),30.

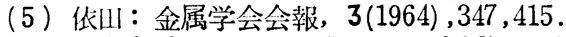

(6) C.Palache: Dana's System of Mineralogy, Vol. 1, 834; Vol.2, 1124(1951).
タル

木 村 啓 造* 佐々木 靖 男**

( $\mathrm{Fe} \cdot \mathrm{Mn})\left(\mathrm{Ta} \cdot \mathrm{Nb}_{6} \mathrm{O}_{6}\right.$ であつてかなり多量の $\mathrm{Nb}$ を含んで いる． $\mathrm{Ta} / \mathrm{Nb}$ 比は一定していないが, Ta が多いものを Tantalite, $\mathrm{Nb}$ の多いものをColumbite と呼び,これら鉣 石は通常 $\mathrm{Nb}+\mathrm{Ta}$ (酸化物)を約 $60 \%$ 含んでいる．黑褐 色の脆い鉱物で Tantalite と呼ばれる あのは $\mathrm{Ta}_{2} \mathrm{O}_{5} /$ $\mathrm{Nb}_{2} \mathrm{O}_{5}$ 比が 12〜8 の程度で, 比重は Ta 比が増すにした がつて大となり 7〜 7.3の範囲である. タンタル石の主 要産地は, アフリカではコンゴ, ナイジェリアなどであ り，アジア地区ではマラヤで錫の副産物として，その他 ブラジル，西ドイッ，オーストラリアのペグマタイト鉱 㦿中に産出し, 主としてアメリカへ輸出されている(1). その他 $\mathrm{Nb}$ の鈗石中には必ず Ta が含まれているためこ れらも重要な鉱石といらことが出来る.コロンバイト (Columbite), パイロクロアー (Pyrochlore) [NaCa (Nb, $\left.\mathrm{Ta})_{2} \mathrm{O}_{6} \mathrm{~F}\right]$, ユークセナイト(Euxenite) $[(\mathrm{Y}, \mathrm{Ca}, \mathrm{Ce}, \mathrm{U}, \mathrm{Th})$ $\left.(\mathrm{Nb}, \mathrm{Ta}, \mathrm{Ti})_{2} \mathrm{O}_{6}\right]$ などは $\mathrm{Ta}$ よりも $\mathrm{Nb}$ を多く含んでい るが, 近年 $\mathrm{Nb}$ の生産の増大に伴なつて, 副産物として 回収される $\mathrm{Ta}$ 量も増加している.

一方わが国では Ta の資源はほとんど発見されず，輸 入に頼つている．わが国の 金属 Ta の 製産は 36 年度に 颃いて $240 \mathrm{~kg}$ の程度で, 同年の輸入 $1720 \mathrm{~kg}$ と併せて 約 $2 \mathrm{t}$ であつた(7). 国内需要の約 $80 \%$ は Ta コンデン サーおよび電気関係部品であるが，高温炉の発熱体また は化学工業用耐食材料などの工業材料方面の需要も増加 しつつあり, 今後数年間に世界需要は約 $600 \mathrm{t} /$ 年と推定 されている.

\section{Ta の 精 錬}

\section{(1) 鉱石の処理}

鉱石の種類， Ta 含有量および随伴有洒金属の種類な どによつて種々な方法を組み合わせることができる。

(a) 弗化水素酸法：40 60\% HF を用い，約 $60^{\circ} \mathrm{C} て ゙$ 処理する方法であつて, $\mathrm{Ta}, \mathrm{Nb}$ 量の高い鉙石に適用さ れ, 現在最も広く行なわれている(2)(8).

(b) 弗素法：反応容器内で加熱しながら非素がスを通 じて弗化物としたのち抽出する(2).

（7）新金属データーブック，(1962〜3),78.

(8) H.A.Wilhelm : U.S. A.E.C. Rept. ISC-644, (1956) ,7 . 
(c) 塩素法：すでに Ti $\mathrm{Zr}$ に実用されている塩素 法の応用であつて，粉鈗に黒鉛を加えて高温に加熱しな がら $\mathrm{Cl}_{2}$ ガスを通じ揮発性の $\mathrm{TaCl}_{5}$ として抽计する(9).

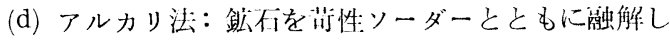
たのち水で抽出し,さらに $\mathrm{HCl}$ 抽出を行なら方法で低 品位鈆の処理をもできるが、 コストが高いため現在はほ とんど行なわれていない。

(e) 硫酸法： $98 \% \mathrm{H}_{2} \mathrm{SO}_{4}$ と $\mathrm{Na}_{2} \mathrm{SO}_{4}$ とを加えて加熱 乙，硫酸塩として抽出する.

\section{(2) $\mathrm{Ta}$ と $\mathrm{Nb}$ の分離}

弗化タンタル酸カリ $\left(\mathrm{K}_{2} \mathrm{TaF}_{7}\right)$ と $\mathrm{K}_{2} \mathrm{NbF}_{7}$ の水に対す る溶解度の差を利用する再結晶法は歴史的には有名であ るが(1)〜(3)，効率が悪いため現在は用いられない．

有機溶媒抽出法が工業的に広く適用されている. 弗 酸法で抽出した $\mathrm{Ta}, \mathrm{Nb}$ 溶液を使い, Methy1 Isobuty1 Ketone (MIBK) に上る方法が今日では一般 に工業的に採用され, 約 $2 \mathrm{~N}$ の $\mathrm{HF}$ 酸性で 数段の 抽出操作を組み合わせることによ り，ほとんど完全に分離されている，第1 図に $\mathrm{HF}$ 酸性での MIBK による $\mathrm{Ta}$ と $\mathrm{Nb}$ の抽出率を示す(10)(2).

\section{（3）金属への遺元}

Ta 金属は種々な方法によつて作ること ができるが，工業的に応用されているもの は Na 還元法, 電解法扮よび炭化物還元法 であるが，第 2 図a,b,cよりも明らかなよ らに実験室的には種々の組み合わせができ る.

\section{（i）弗化物の金属 $\mathrm{Na}$ 賟元}

$\mathrm{K}_{2} \mathrm{TaF}_{7}+5 \mathrm{Na} \rightarrow \mathrm{Ta}+2 \mathrm{KF}+5 \mathrm{NaF}$ 上記の反応は鋼製のボンベ中に原料を入 れ，外部加熱により反応させる. 冷却した のち水やメタノールを用いて Ta 以外の反 応物や残渣を除き, 酸洗い, 乾燥したのち 粉砕して粉末 Ta を得る。本法は純度もよ く,粒度は -325 メッュの微粉が 40〜60 \%をを占める(11).

\section{(ii) 電 解 法}

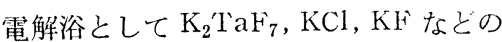
混合塩を用い，約 $900^{\circ} \mathrm{C} て ゙ ~ \mathrm{TaCl}_{5}$ と $\mathrm{Ta}_{2} \mathrm{O}_{5}$ の混合物を 追加供給しながら電解を行なう(12)。この場合添加する

(9) H.T.Sharp: Chemical Eng., 63(1956), 103.

(10) K. B. Higbie and J. R. Wernig: U.S.Bureau of Mines R.I.5239, (1956), 49.

(11) G.I.Miller: Vacuum, 2(1952), 19.

(12) C.W.Balke: Chem. and Ind., (1948), 83.
$\mathrm{Ta}_{2} \mathrm{O}_{5}$ は陵極効果を防ぐ減極剂として効果がある，通常

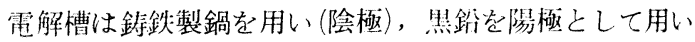

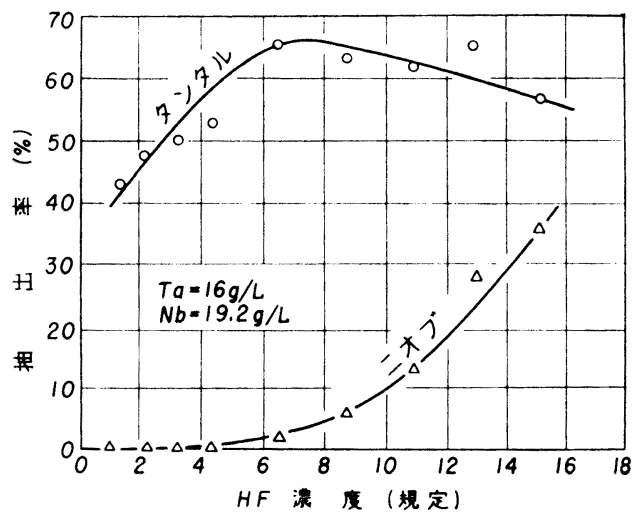

第 1 汹 HF 性溶液でのメチル・イソブチルケトン による Ta 扣よび Nb の抽出䜌

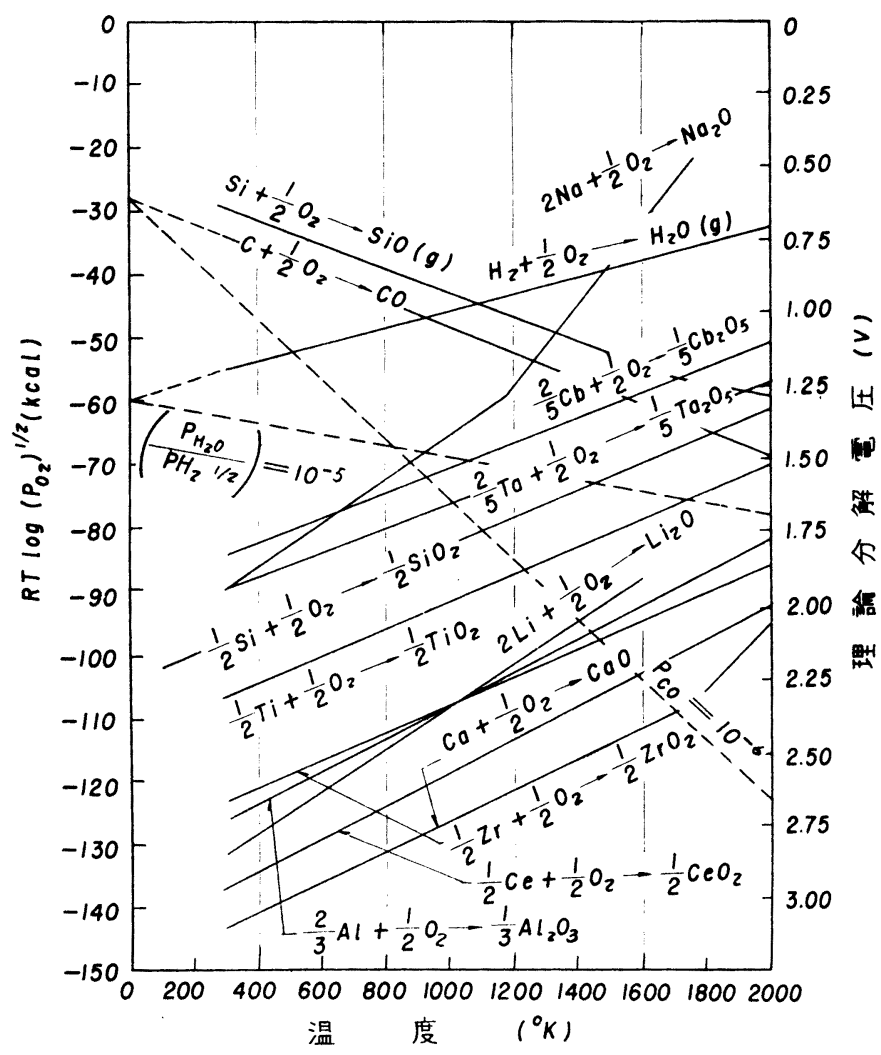

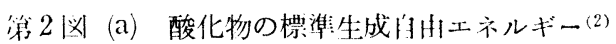

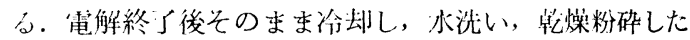
のち酸洗いを行なら．粒度は 200 メッュ以上 $30 \%$ ， 200〜 400 メッッュ 40\%でー400メッシュが残りの 30\% の程度である．純度を向上させる月的で照鉛鍋を陽極と し, 'Ta 棒を陰桠として電解精鍊を行ない，不純分の合 計が $500 \mathrm{ppm}$ 程度の純品が得られている。 
(iii) $\mathbf{T a}_{2} \mathbf{O}_{5}$ の $\mathbf{T a C}$ 遗 元

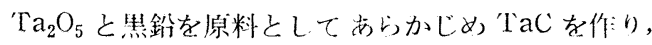

の他の狖祘が低い。

\section{(v) 塩化物の $\mathbf{M g}$ 遺元}

$\mathrm{TaCl}_{5}$ または $\mathrm{TaCl}_{3}$ を $\mathrm{Mg}$ で還

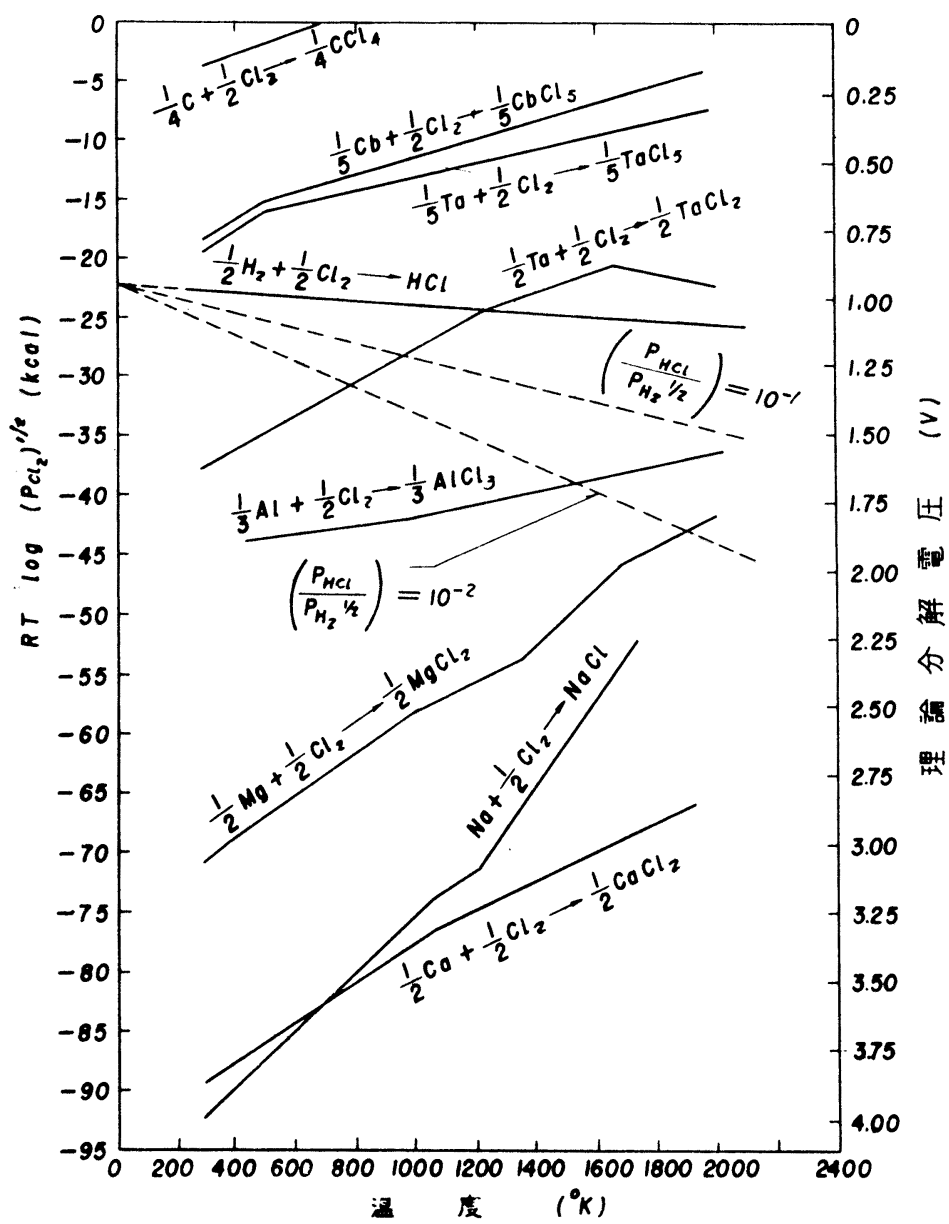

第2脑 (b) 缩化物の標潐牛成自由エネルギー(2) 元する方法は $\mathrm{Ti}$ や $\mathrm{Zr}$ と同様仁可 能であり, $\mathrm{Mg}$ 以外の $\mathrm{Na}, \mathrm{Ca}$ など る使うことが出来る(15). また $\mathrm{TaCl}_{5}$

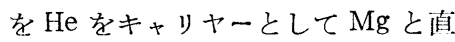
接反応させることる考えられている が(16)，無水塩化物の取り扱い上の 問題があるため工業的には採用され ていない。

\section{(vi) その他}

$\mathrm{TaCl}_{5}$ は約 $2000^{\circ} \mathrm{C}$ に加熱された Ta 線上に送られると, $\mathrm{TaCl}_{5} \rightarrow \mathrm{Ta}$ (s) $+5 \mathrm{Cl}(\mathrm{g})$ の熱分解を起す(17).

その他酸化物 $\left(\mathrm{Ta}_{2} \mathrm{O}_{5}\right)$ 上り㨁接に 金属 Taへの還元子種々試みられて いるが(18), Ta 中に酸素が不純分と してかなり多量に残留するため実用 には至つていない，近年電子ビーム 溶解技術が進歩し, 後述するように E.B.M.法では溶解中に精製効果が 两るために原料 $\mathrm{Ta}$ 金属中の $\mathrm{O}, \mathrm{N}$ ， Hなどは特定の場合を除いてはほと んぞ問題とならないが，焼結して用 いる場合にはその用途とも関連して 㛟討する必要がある.

\section{Ta の造塊}

Ta は融点が高いため, 初期は焼

ついで $5 \mathrm{TaC}+\mathrm{Ta}_{2} \mathrm{O}_{5} \rightarrow 7 \mathrm{Ta}+5 \mathrm{CO}$ の反応により $\mathrm{Ta}$ を得る。度は $2000^{\circ} \mathrm{C}$ 以上の高温度を必要と寸るため, 高周波電気灯を用い真空中で加䓡する。比較的大きいべ レット状 Ta が得られるのでーー水素処理したのち粉础

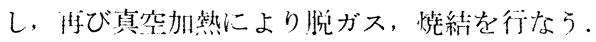

\section{(iv) 塩化物の水素僄元法}

$\mathrm{TaCl}_{3}$ または $\mathrm{TaCl}_{5}$ の水素遄元は第 2 闵(b) 上りも明 らかなよ5に，Ta金属を得ることができる(13)。高温度 では Ta 以外は気体であるため過剩の水素を用いること によって所定の位置に Ta を集めることが汁来，500 $\mathrm{C}$ に加熱した Ta 板を使つて平滑な析洁が得られ，650 では粉末が得られる(14). 本法は純度はよいが步留りそ

(13) O.Kubashewski and E.L.Evans: Metallurgical Thermochemistry, (1956), 410

(14) A.B.McIntosh et al: Extraction and Refining. of the Rare Metals, Inst.Min.Met., (1957),272.
絬法にのみ頼つていたが，アーク灿拈よび電子ビーム炉 の進少により大型の熔解も出来るょ5になり，板や線材 などは今後 E.B.M. 法によりキキャ゚シターなどの特 殊用途(19)には焼結法により生産されるようになつた。

(a) 粉末治金: 粉末の圧繀, 真空焼絬上の反応を要 約すれば(4)(20)，(1) 吸着ガスの放出； $400^{\circ} \mathrm{C}$ まで，(2) 水素の離脱; $650^{\circ} \mathrm{C},(3)$ 一部焼結開始; $1200^{\circ} \mathrm{C},(4)$

(15) 传伯, 大森：工業化学雑誌, 66 (1963),1283.

(16) H.A. Johansen and S.L.May: Ind .Eng. Chem., 46 (1954), 2499.

(17) W. G. Burgers and J.C.M. Basart : Z. Anorg. allgem.Chem., 216 (1934), 223.

(18) C. K. Gupta and K. P. Jena: J. Less-Common Metals, 8(1965), 90 .

(19) L.H.Belz: Reactive Metals, Interscience Publ., (1959), 525 .

(20) R.H.Myers: Metallurgia, 38(1948), 307. 
$\mathrm{N}(21), \mathrm{C}, \mathrm{O}(22)$ の離脱 $1600^{\circ} \sim 1900^{\circ} \mathrm{C}$, (5) 酸化物の蒸発 $2000^{\circ} \sim 2300^{\circ} \mathrm{C},(6)$ 金属 $\mathrm{Ta}$ の蒸発； $2450^{\circ} \mathrm{C}$ 以上であ
れている(4).

（c）電子ビーム溶解：溶融金属が長い時間にわたつて 高い真空度で保持調節されるので, 脱ガス や不純分の揮発などによる精製効果が大き く，極めて良質のインゴットを容易に得る ことができる，精製効果は蒸気圧の高い成 分が高温高真空のため除去されることによ るもので, 蒸気圧 ${ }^{(24)}$ の比は $\mathrm{TaO} / \mathrm{Ta} \fallingdotseq 104$ 程度であるため酸素は容易に除去される. また Ta 中のCは極めて安定であるが, 過 剩の○が存在するときは $\mathrm{CO}$ を形成するた め, $\mathrm{CO}$ として容易に除去され, 未反応の $\mathrm{O}$ は $\mathrm{TaO}$ として除去されることは Nbの 場合 ${ }^{(25)}$ と同様に容易に理解できるである 3 .

電子ビーム溶解については本号に解説 (26) がある他, 増田ら (4) によつても詳細が のベられている.

\section{Ta の 加 工}

\section{(1) Ta の塑性加工}

Ta は極めて靱性で 展延性に富及，第3 図(2)に示すよ5に，常温加工に伴な5加工 硬化をほとんど起さないので, かなりの強 加工を与えることができる.インゴットは 一般に結晶粒も粗大化し鋳造組織をむつて いるので, 最初に注意してこれらを破壊す
る・したがつて粉末は压縮成型したのち真空中で約 2600 ${ }^{\circ} \mathrm{C}, 1 \sim 2 \mathrm{hr}$ の加熱をすれば，精製効果があるため冷間 加工のできる Taインゴットを得ることができ, 增田ら により詳細がのべられている(4).

(b) Taのアーク溶解：いずれの様式も応用できる が，W電極を用いる非消耗式電極型ではWの混入の括 それがある他，E.B.M.に見られる脱ガス効果は得ら れない。これに対し消耗電極型の真空アーク溶解に括 いては品位のよい原料 Taを使うことにより健全なイ ンゴットを得ることが出来る(4). 溶解条件の一例を示 すとつぎのようである.

自溶電極径約 $50 \mathrm{~mm}$ の場合メカニカルブスターを 用い, 真空度 $2 \sim 5 \mu$, 電圧 $30 \mathrm{~V}$, 電流 $4500 \sim 5000 \mathrm{~A}$ で約 $250 \mathrm{~g} / \mathrm{min}$ の溶解速度で 約 $100 \mathrm{~mm} \phi$ のインゴッ トを得ることが出来(23)，増田らにより取りまとめら

(21) M. R. Andrews: J. Am. Chem. Soc., 54(1932), 1845.

(22) R.Titterington and A.G. Simpson: Symposium on Powder Metallurgy, Iron and Steel Inst. London, (1956) .

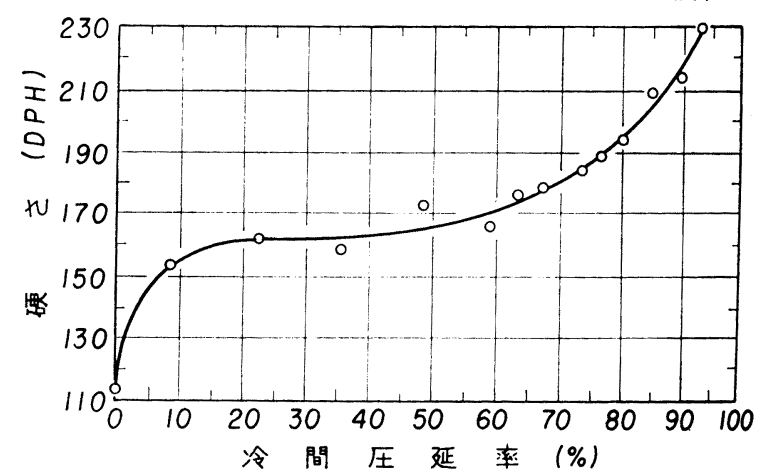

第3 図 アーク溶解した Ta の常温加工硬化曲線(2)

(23) M.L.Torti : J.Electrochem. Soc., 107 (1960), 33.

(24) D. R. Stull and G. C. Sinke : Thermodynamic Properties of the Elements,Amer.Chem. Soc., (1956) .

（25）木村, 佐々木：金属学会誌, 29(1965), ,No.9.

（26）津谷：金属学会会報, 4(1965)，569。 
dzimir)によつて $0.02 \mathrm{~mm}$ ないし数ミクロンの䇴を作る ことも出来る.

鍛造, スェージ加工, ヘラ加工拉よび絞り加工なども 軟鋼と同様に考えて取り扱うことが出来る. 深絞りは 1 回当り径の $40 \sim 50 \%$ 以内で行ない, 複雑な加工も可能 である. 線引きは超硬工具またはダイヤモンド・ダイス (0.5 mm 以下) を使つて細線引きが可能で潤滑剤として 密蟆などを用いる.

Ta の取り扱い上の注意としては（1）焼き付きの防止 のため潤滑または冷却剤を十分に施すこと，扣よび (2) 軟かい材料であるため层をつけないことである。したが つて線引きその他のガイド部分はアルミ青銅製のじぐ, 工具を用いて Taを保護する. 管の製造は板材を溶接し たのち引抜きによつて所定の寸法に仕上げて作る.

焼きなましは約 $60 \%$ 程度の泠間加工を与えたとき行 な5のが標準で, 真空 $(1 \sim 3 \mu)$ 中約 $1200^{\circ} \mathrm{C}$ に $3 \mathrm{hr}$ の熱 処理を行なう。

\section{(2) 機 械 加 工}

Ta は焼き付きやすい性質をるつているため切削油を 十分に施すことが必要で, 普通の切削油に同量の四塩化 炭素またはトリクロルエチレンなどを混合したものが推 奨される. 旋盤加工の場合切削速度は 100 $20 \mathrm{~m} / \mathrm{min}$ で 切り込みを深くし, 送り速度は 1 回転当り $0.15 \sim 0.17$ $\mathrm{mm}$ の条件でたとえば第 4 図に示したよ5な鋭いバイト

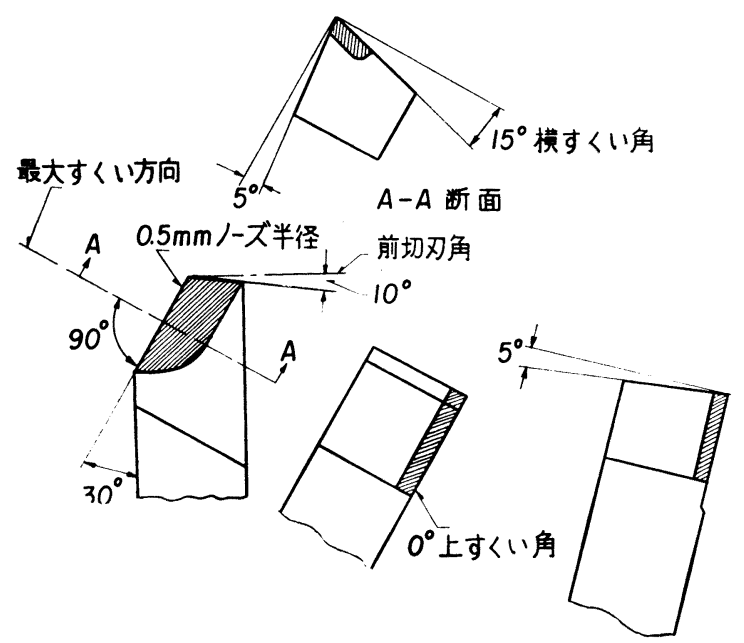

第 4 図 タンタルを加工する場合のバイトの形状

を用いることが推桨されている(27)，穴あけなどは通常 のハイス製工具を用い, 多量の切削油を用いて純 Ta に ついては銅とほぼ同様に取扱う。

\section{(3) Ta の 研 庶}

(27) Anon: Machinery (London) ,82 (1953), 72.
Taは軟いため通常のグラインダーによる研摩は困難 であるが，極軟質の砥石またはエメリ一紙を用い，十分 多量の潤滑剂(四塯化炭素など)を用いて研摩を行ならこ とができる、一般にバフ研摩の方が適当している.

\section{(4) $\mathbf{T a}$ の 溶 接}

$\mathrm{Ti}$ や $\mathrm{r}$ などの活性な金属と同様に真空中または不活 性ガス雾囲気中で安全に溶接することができる. Taは 室温では極めて安定であるが, 後述するよ5に数百度以 上の空気中または酸素, 窒素などを含む雲团気中では污 染を受け，機械的性質が著しく劣化するので注意が必要 である.

Ta の融点が高いことは薄板の溶接に有利で, 0.03 $\mathrm{mm}$ の䈃の溶接も可能とされている. Ta 板の溶接はフ ィラーを用いず，薄板では突き合わせ端を約 $1 \mathrm{~mm}$ ほど 折り曲げた上タングステン電極またはヘリアーク・ガン を用いて行なう．ただしやや厚い板では通常のよ5に Ta 線をフィラーとして使うことも行なわれている。

Ta の溶接に当り注意することは不純分 (ことに酸素) による污染を防ぐことが最も大切である.したがつて使 用するアルゴンまたはヘリウムの純度に注意し, 保護箱 内は常に清潔にしてガスの純度を保つとともに品物の脱 脂を溶接前に必ず行なうことが必要である. 油分は溶接 時の高熱で分解されて ○やCの污染の原因となるため, 四塩化炭素などで充分に除去しておく.

電子ビーム溶接は極めて有効な溶接方法であるが(28), な怙溶接部ならびに熱影響部は結晶粒の粗大化を起すた め急冷することが望ましい，W， Zr, Ni， Fe その他の異 材への溶接も行ならことができる。 また焼結法で作られ た素材ではC抽よ゙゙○などの不純分を多く含もものがあ るが, このような材料は溶接部に気孔が多数発生するこ とがあり, TIGょりも高真空中の電子ビーム溶接により 多く発生する. 溶解材にはこの危険がない.

\section{(5) 熱処 理}

焼きなましは $10^{-5} \mathrm{mmHg}$ 以上の高真空中で行なうこ とが必要である。焼さなまし温度はTaの純度拈よび履 歴(加工度)によつて異なるので一概には決められない. 不純分の少ない電子ビーム溶解材を $90 \%$ 加工した場合 では約 $1200^{\circ} \mathrm{C}, 1 \mathrm{hr}$ とされているが, 粉末治金による素 材では一般に不純分量が多いので, 同じ程度の加工を与. えても再結晶温度は高く, したがつて焼きなまし温度は $1200^{\circ} \sim 1400^{\circ} \mathrm{C}, 1 \sim 3 \mathrm{hr}$ が適当とされている.

\section{6. 物 理 的 性 質}

Ta の物理的諸性質を第 1 表にとりまとめて示す(1)

(28) 鈴木, 橋本, 松田：金属材料技術研究所研究報告, 5 (1962) , 256 . 
(3) (29).

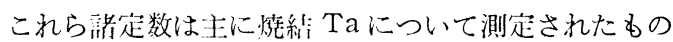

空孔などの相互作用によつて企壯效現像や延性刘脆性遷 移温度に大きな影響を与える. これら浸入型元素の $\mathrm{Ta}$ 第 1 表 $\mathrm{Ta}$ の 物 理 的性質

\begin{tabular}{|c|c|c|c|c|c|}
\hline 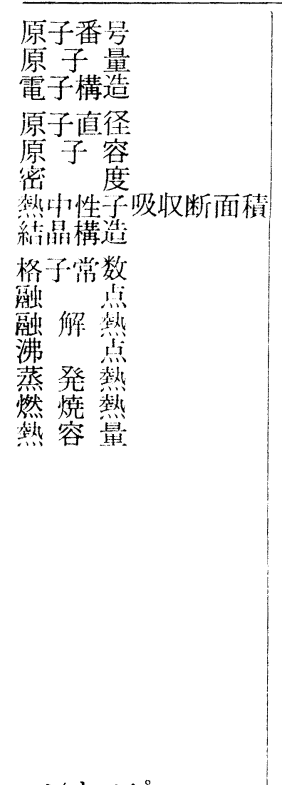 & 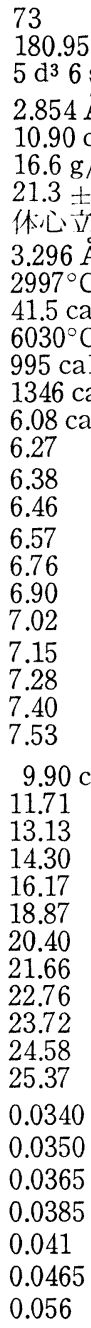 & 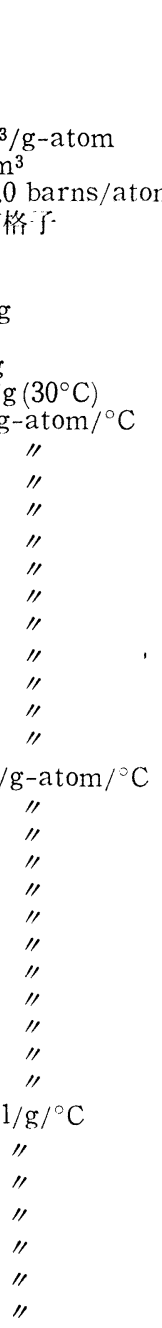 & 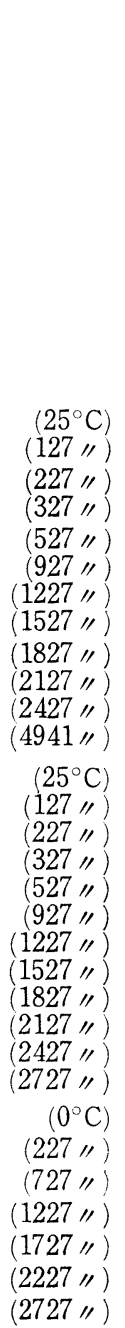 & 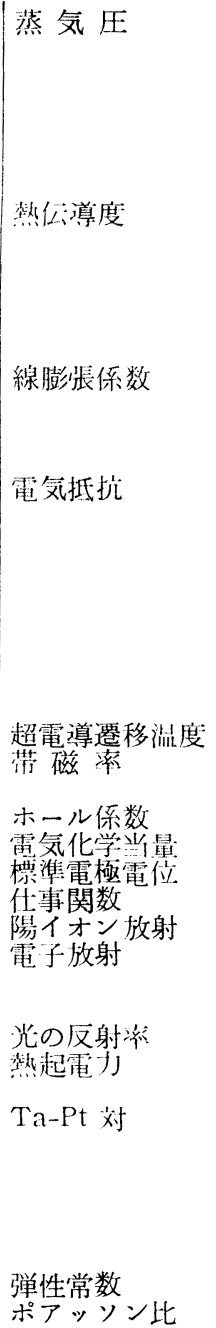 & 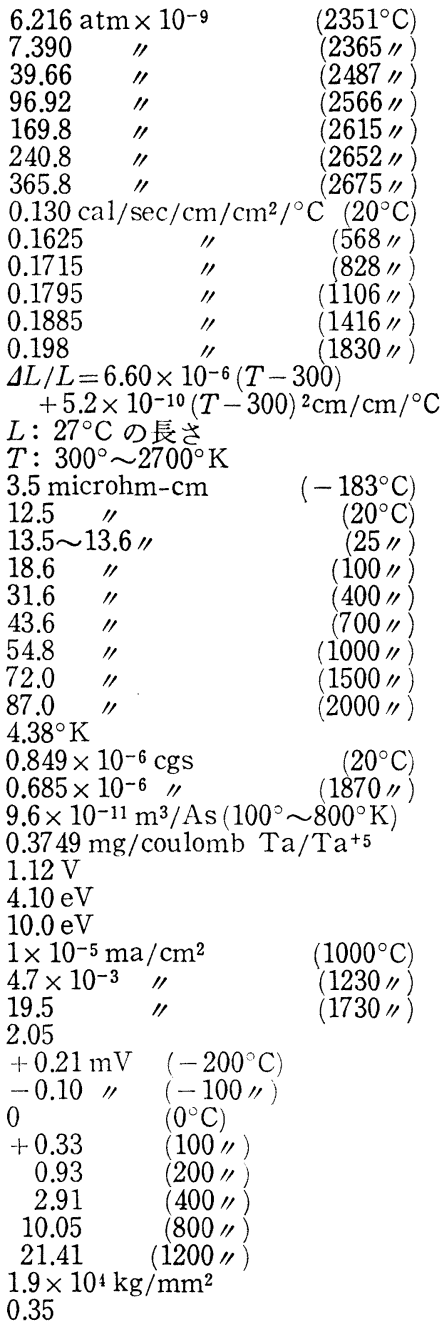 \\
\hline
\end{tabular}

である。しかしながら近年高純度 Ta の製尷が容易にな つたため,これら物理的諸定数々值は純度の向上:にもと づく若干の変化があるのは当然であろう.

$\mathrm{Ta}$ は $\mathrm{Nb}$ や $\mathrm{Fe}$ の場合と同様不純物としての浸入型 元素によつてその物理的機械的性質に大きな影響を受け る. Taに対する $\mathrm{C}, \mathrm{N}$ 㧊よびOの固溶度は第 5 図のご とくであり(30) (32)，これら浸入型不純物 元素は転位,

(29) F.F.Schmidt: Tantalum and Tantalum Alloy, DMIC Rept.133, July (1960).

(30) D. A. Vaughan, O. M. Stewart and C. M. Schwartz: Trans. AIME, 221 (1961) ,937.

(31) H.R. Ogden, F.F. Schmidt and E.S. Bartlett : Trans.AIME, 227 (1963), 1458.
けでの昖散恒数，目已拡散恒数などな第 2 表にとりまと める.

迄りは Fe などの 休心立方金属と同様主として (110) 面で起り, 迄り向向は<111>である(39) (42). $-196^{\circ} \mathrm{C}$ では双晶変形が起りその双晶面は (112)である(42). 双晶 は Nb の場合と同様大結晶粒, 高純度, 低温ほど起りや すい. Ta 板の主な圧延集合組織(43) は $(112)<011>$ で あり， $(100)<011>と(111)<112>$ 成分を含んでいる. 焼鈍回復の段階で $(112)<011>$ が強められるが，再結 晶過程で $(100)<011>$ と $(112)<011>$ 打问の組織は消

(32) P.Bunn and C.Wert: Trans.AIME, 230 (1964), 936. 


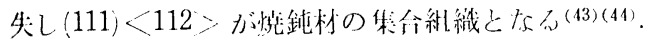

降伏值の温度，引張り涑さ，結唱粒度などの依存性に

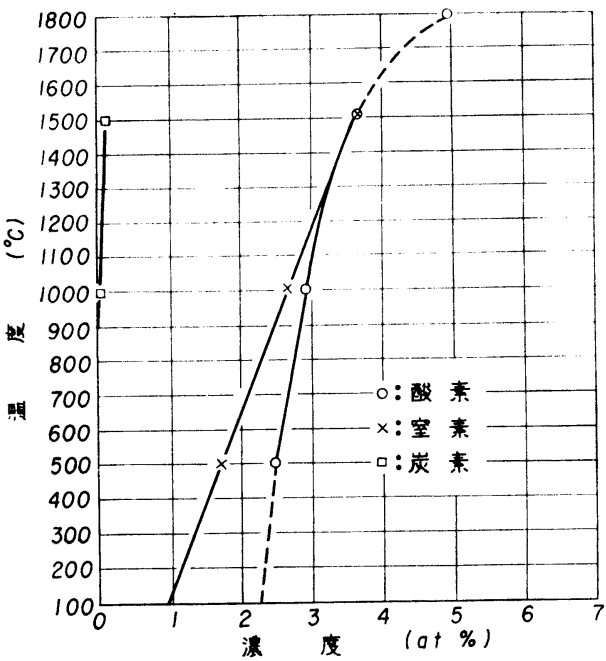

第 5 図 タンタル中への酸素, 窒素拈よび 炭菜の国溶度(30) (32)

ついては，すでに多くの解告があるが純 Fe の場合とほ ほ同様の絬果を得ている(45)〜(47)。

第 2 表 Ta の自己拡散执よび Ta 中の浸入型諸元 素の抬散恒数

\begin{tabular}{|c|c|c|c|c|c|}
\hline 元 & 払 & 散 & 怕 & 数 & 献 \\
\hline $\begin{array}{l}\mathrm{Ta} / \mathrm{Ta} \\
\mathrm{H} / \mathrm{Ta} \\
\mathrm{O} / \mathrm{Ta} \\
\mathrm{N} / \mathrm{Ta} \\
\mathrm{C} / \mathrm{Ta}\end{array}$ & $\begin{array}{l}2 \\
0.0214 \\
0.019 \\
0.0123 \\
0.015\end{array}$ & $\begin{array}{l}\exp \\
\exp \\
\exp \\
\exp \\
\exp \end{array}$ & $\begin{array}{l}-110, \\
-9,37 \\
-27,3 \\
-39,8 \\
-39,6\end{array}$ & $\begin{array}{l}0 / R T) \\
R T) \\
/ R T) \\
/ R T) \\
/ R T)\end{array}$ & $\begin{array}{l}(33)(34) \\
(35) \\
(36) \\
(36)(37) \\
(38)\end{array}$ \\
\hline
\end{tabular}

(33) P.L.Gruzin and V.I.Meshkov: Vestnik Akad. Nauk Kazakh. U.S.S.R., 11 No.4, (1955) , 85.

(34) R.L. Eager and D.B. Langmuir: Phys.Rev., 89 (1953) ,911.

(35) W.M.Albrecht,W.D.Goode and M.W. Mallett: J.Electrochem.Soc., $106(1959), 981$.

(36) C.Y.Ang: Acta Met., 1 (1953) , 123

(37) R. W. Powers and M. V. Doyle: Acta Met., 4 (1956) , 233.

(38) R.W.Powers and M.V. Doyle: J. Appl. Phys., 28 (1957), 255

(39) R.Bakish: Acta Met., 6(1958), 120.

(40) D.P.Ferriss, R.M.Rose and J.Wulff: Trans. AIME, $224(1962), 975$.

(41) B.L.Mordike: Z.Metallk., 53(1962) ,586.

(42) C.S.Barrett and R.Bakish: Trans.AIME, 212 (1958), 122 .

(43) J.W.Pugh and W.R.Hibbard: Trans.ASM, 48 (1956), 526 .

(44) C. G. Dunn and H. F.Webster: Trans. AIME, 230 (1964), 1567.

(45) R.J.Arsenault: Trans. AIME, 23J (1964), 1570

(46) B.Harris: J.Less-Common Metals, 5 (1963), 195

(47) R.C.Koo: J.Less-Common Metals, 4 (1962), 138.

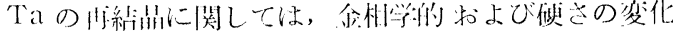
から㛟就した Schmidt ら(48)の詳紐な研究があり，その

第 3 表電子ビーム溶解 Ta $91 \mathrm{hr}$ 加熱処理に よる再結晶度と加熱温度

\begin{tabular}{|c|c|c|c|c|}
\hline 加 & 工 履 & 歴 & $50 \%$ 再結晶 & $100 \%$ 再結皿 \\
\hline \multicolumn{3}{|c|}{$\begin{array}{l}50 \% \text { 冷間压延: } \\
75 \% \text { 冷間圧延: } \\
95 \% \text { 冷間压延 } \\
\text { 中間烧鈍後 } 75 \% \text { 冷延 }\end{array}$} & $\begin{array}{l}1100^{\circ} \mathrm{C} \\
1000 \\
900 \\
1050\end{array}$ & $\begin{array}{l}1400^{\circ} \mathrm{C} \\
1200 \\
1300 \\
1200\end{array}$ \\
\hline
\end{tabular}

結果を第 3 表に要約した，完全再結晶を行なうためには $1200^{\circ} \mathrm{C}$ 以上 $1 \mathrm{hr}$ の真空加熱が必要である.

焼鈍再結晶にともなら硬度の变化は第 6 図のようにな る(48)。查焼鈍法による再結晶粗大化の前処理最適歪量 は $2127^{\circ} \mathrm{C}, 4 \mathrm{hr}$ の加熱処理のとき $2.5 \%$ あ゙す, 結晶粒 の直径は $7 \mathrm{~mm}$ に達した ${ }^{(49)}$.

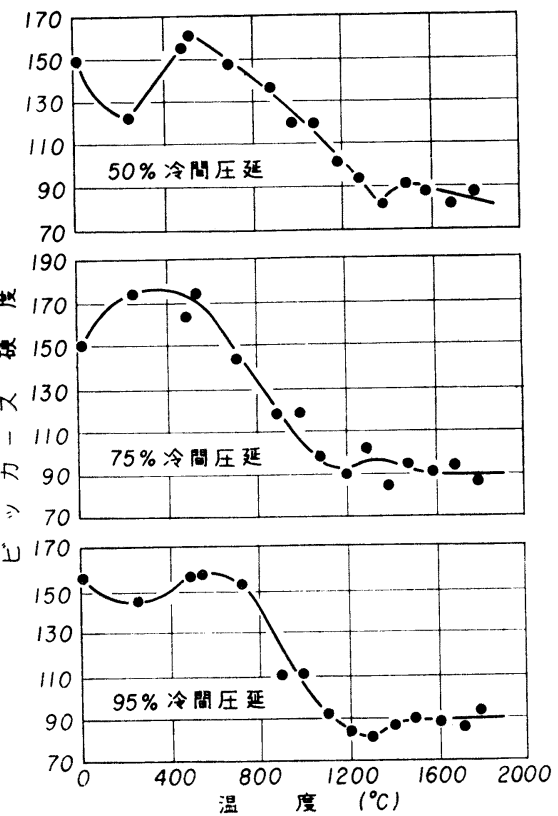

第6网 高純度タンタルの焼鈍にともなう 硬度の低下

アーク溶解材の $1 \mathrm{hr}$ 加熱焼鈍の場合の再結晶図を第 7 図に示した ${ }^{(50)}$ 。この図から明らかなように $1300^{\circ} \sim 1400$ ○の加熱が均一な微細結晶粒を得る最適条件と考兄ら れる。

(48) F.F.Schmidt, W.D.Klopp, W.M.Albrecht, F. C.Holden, H.R.Ogden and R.I.Jaffee: Battelle Memorial Inst., WADD - TR - No. 59 - 13 (Dec. 1959) .

(49) B.A.Mrowca: J.Appl.Phys., 14(1943), 684.

(50) E.M.Savitskii, M.A.Tykina and I.A.Taygonova: Doklady Akad. Nauk SSSR, 118 (1958), 720 . 


\section{7. 機械 的 性 質}

(1) $\mathrm{Ta}$

$\mathrm{Ta}$ の機械的性質は 他の 体心立方 金属の 場合と 同様 C, N, O などの浸入型不純物元素によつて大きな影響を

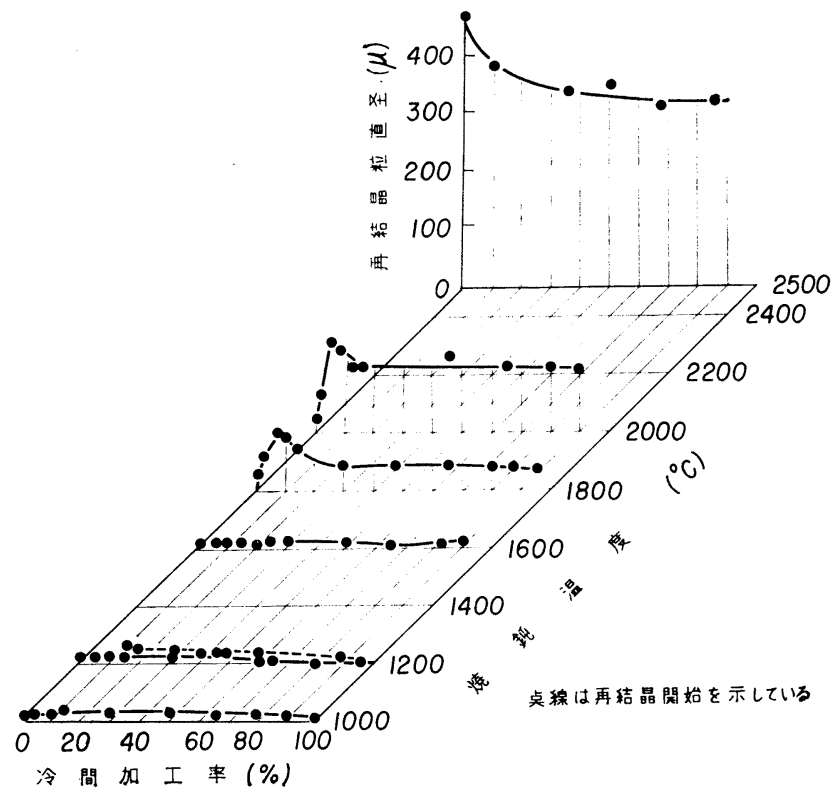

第7図 アーク溶解材 $\mathrm{Ta}$ の再結晶線図 ( $1 \mathrm{hr}$ 加熱の場合)
数十 ppm 含む電子ビーム溶解高純度 $\mathrm{T} a$ に比べて, そ の低温強度のみならずその高温機械的強度も著しく增大 する(51)。これら浸入型元素による機械的強度の変化の 一例を第 4 表に示す.

浸入型元素のうち C がもつとも著しい強化効果を示 し，乙かも長時間クリープの場合 $\mathrm{O} \mathrm{N}$ の効 果が減少するのに反し, その強化効果はか兄 つて增大する．また引張り試験前に試験片を 種々の温度で大気中に保持し, 大気污染によ る常温引張り強さの著しい増大をみとめた. 高純度 Ta の常温引張り強さは約 $20 \mathrm{~kg} / \mathrm{mm}^{2}$ 切欠き感度は鈍人，応力一歪線に打いて降伏 点をはつきりとみとめられない場合が多い。 これに反し焼結 Taでは常温に执いて降伏現 象がみられるばかりでなく，歪時効にもとづ く降伏の再現が容易である.

高純度 $\mathrm{Ta}$ の加工材と焼鈍材の機械的性質 を第 5 表に示した。 いら゙れの場合も $300^{\circ} \mathrm{C}$ 前 後に極くわずかであるが, 引張り強さの増大 と伸びの減少がみとめられる.

Ta の高温引張り強さについては多くの研 究(52) (56) がなされているが，いずれの素材 の場合でも $300^{\circ} \mathrm{C}$ 前後に強度伸びの不連続が みとめられ，この現象は浸入型不純物元素に

第 4 表 $\mathrm{Ta}-\mathrm{O}(\mathrm{O}: 560 \mathrm{ppm})$ 合金, Ta-N (N: $225 \mathrm{ppm})$ 合金, Ta-C (C: $995 \mathrm{ppm})$ 合金执よび電子ビーム溶解 Ta の高温クリープラプチャ一強度

\begin{tabular}{|c|c|c|c|c|c|c|c|c|}
\hline \multirow{2}{*}{ 温 } & \multirow{2}{*}{ 時 ${ }^{\text {間 }}$} & \multicolumn{4}{|c|}{ ラプチャ一強度 $\left(\mathrm{kg} / \mathrm{mm}^{2}\right)$} & \multicolumn{3}{|c|}{ 強 度 増 加率 (\%) } \\
\hline & & $\mathrm{Ta}$ & $\mathrm{Ta}-\mathrm{O}$ & $\mathrm{Ta}-\mathrm{N}$ & $\mathrm{Ta}-\mathrm{C}$ & $\mathrm{Ta}-\mathrm{O}$ & $\mathrm{Ta}-\mathrm{N}$ & $\mathrm{Ta}-\mathrm{C}$ \\
\hline $\begin{array}{l}750 \\
" 1 \\
" 1 \\
\text { " }\end{array}$ & $\begin{array}{r}0.1 \\
1.0 \\
10.0 \\
100.0\end{array}$ & $\begin{array}{r}11.95 \\
11.25 \\
10.55 \\
9.84\end{array}$ & $\begin{array}{r}15.82 \\
12.30 \\
10.55 \\
9.84\end{array}$ & $\begin{array}{l}17.78 \\
15.82 \\
13.71 \\
11.95\end{array}$ & $\begin{array}{l}20.3 \\
19.7 \\
19.0 \\
18.3\end{array}$ & $\begin{array}{r}32 \\
9 \\
0 \\
0\end{array}$ & $\begin{array}{l}47 \\
41 \\
30 \\
21\end{array}$ & $\begin{array}{l}71 \\
75 \\
80 \\
86\end{array}$ \\
\hline
\end{tabular}

第 5 表 高純度 Ta の加工材と再結晶焼鈍材の引張り強さと伸び

(a) 加工材

\begin{tabular}{|c|c|c|c|c|}
\hline$\frac{{ }^{3} \text { 温度 }}{\left({ }^{\circ} \mathrm{C}\right)}$ & $\begin{array}{l}\text { 引張強さ } \\
\left(\mathrm{kg} / \mathrm{mm}^{2}\right)\end{array}$ & $\begin{array}{l}\text { 降伏強さ } \\
\left(\mathrm{kg} / \mathrm{mm}^{2}\right)\end{array}$ & $\begin{array}{l}\text { 伸び } \\
(\%)\end{array}$ & 備 \\
\hline $\begin{array}{r}27 \\
150 \\
245 \\
310 \\
365 \\
490\end{array}$ & $\begin{array}{l}42.5 \\
33.9 \\
33.0 \\
34.9 \\
37.5 \\
32.1\end{array}$ & $\begin{array}{l}34.5 \\
31.6 \\
30.9 \\
33.7 \\
35.5 \\
31.7\end{array}$ & $\begin{array}{l}- \\
6 \\
4 \\
5 \\
5 \\
5\end{array}$ & $\begin{array}{l}\text { 電子ビーム溶解 } \\
\text { インゴット } \rightarrow \\
95 \% \text { 冷間生延 } \rightarrow \\
\text { 歪取焼鈍 } \\
\left(750^{\circ} \mathrm{C}, 15 \mathrm{~min}\right)\end{array}$ \\
\hline
\end{tabular}

受ける、これら不純物量は素材の製造法によつて大きく 左右される. したがつて Ta の機械的性質を検討するに あたり, 素材の熱処理, 加工法などの履歴とともに素材 の純度について常に考虑されなければならない。

数百 $\mathrm{ppm}$ の $\mathrm{N}, \mathrm{O}, \mathrm{C}$ を含んだ $\mathrm{Ta}$ は, これら元素を (b) 再結晶焼鈍材

\begin{tabular}{|c|c|c|c|c|}
\hline$\frac{\text { 温度 }}{\left({ }^{\circ} \mathrm{C}\right)}$ & $\begin{array}{l}\text { 引張強さ } \\
\left(\mathrm{kg} / \mathrm{mm}^{2}\right)\end{array}$ & $\begin{array}{l}\text { 㦀伏強さ } \\
\left(\mathrm{kg} / \mathrm{mm}^{2}\right)\end{array}$ & $\begin{array}{l}\text { 伸び } \\
(\%)\end{array}$ & 備 \\
\hline $\begin{array}{r}27 \\
230 \\
325 \\
390 \\
425 \\
490\end{array}$ & $\begin{array}{l}20.7 \\
19.6 \\
21.9 \\
21.2 \\
19.8 \\
19.0\end{array}$ & $\begin{array}{l}18.5 \\
5.98 \\
4.71 \\
\overline{4.50} \\
4.50\end{array}$ & $\begin{array}{l}36 \\
23 \\
30 \\
25 \\
23 \\
20\end{array}$ & 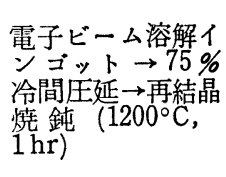 \\
\hline
\end{tabular}

(51) F. C. Holden, F. S. Schwartzberg and R.I . Jaffee: Symposium on Newer Metals, ASTM, Spec.Tech.Publ. No.272, (1960).

(52) M.Schussler and J.S. Brunhouse : Trans.AIME, $218(1960), 893$.

(53) J.W.Pugh: Trans.ASM , 48 (1956) ,677

(54) B.L.Mordike: J.Inst.Met., 88 (1959 60) , 272.

(55) J.H.Bechtold: Acta Met., 3(1955), 249. 
よる歪時効にもとづくものと考学られる，第 8 図に電子 ビーム溶解材とアーク溶解材の高温引張り強さ, 降伏強
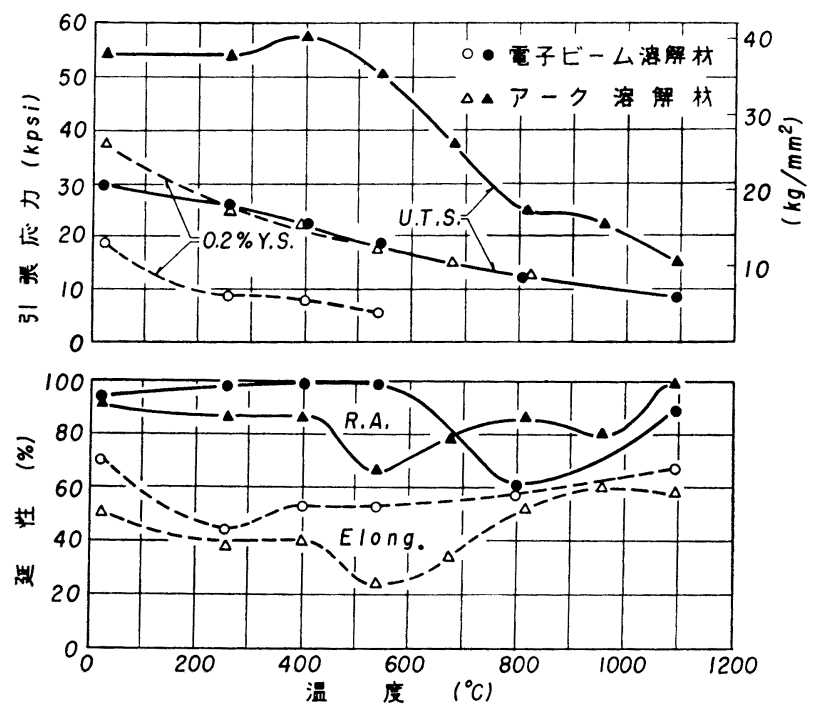

第 8 図 再結晶材の引張り性質に扣よぼす温度の影響(2) U.T.S.; 引張り強さ, Y.S. ; 降伏強さ, R.A. ; 断面収縮率, Elong.; 伸び

さ，伸び执よび断面収縮率を示す，この図比执いて明ら かにアーク溶解材の昜合 $300^{\circ} \sim 400^{\circ} \mathrm{C}$ で引涱り強さや 伸びの折れ部が存在している，一方Pugh(53)による焼結 材についての研究結果を第 6 表に示すが, $300^{\circ} \mathrm{C}$ 前後に 引張り強さのみならず降伏值, 伸び, 加工硬化係数や奀 速度感度係数の不連続性が明らかにみとめられる。すな わち歪時効現象のみとめられる領域では加工硬化係数は 最大となり，歪速度感度係数が最小となつている。

第６表 再結晶焼鈍 Ta 板 (ASTM 粒度 6 7) の引張り強さの温度依存性について

\begin{tabular}{|c|c|c|c|c|c|}
\hline$\left({ }^{\circ} \mathrm{C}\right)$ & $\begin{array}{l}0.2 \% \text { 昰降 } \\
\text { 伏强さ } \\
\left(\mathrm{kg} / \mathrm{mm}^{2}\right)\end{array}$ & $\begin{array}{l}\text { 引張り強 } \\
\text { さ } \\
\left(\mathrm{kg} / \mathrm{mm}^{2}\right)\end{array}$ & $\begin{array}{l}\text { 伸び } \\
(\%)\end{array}$ & $\begin{array}{l}\text { 加工硬 } \\
\text { 化係数 } \\
m\end{array}$ & $\begin{array}{c}\text { 䧺速度感 } \\
n \\
n\end{array}$ \\
\hline $\begin{array}{r}-195 \\
-75 \\
25 \\
100 \\
205 \\
320 \\
430 \\
540 \\
655 \\
760 \\
870 \\
980 \\
1095 \\
1205\end{array}$ & $\begin{array}{r}104.1 \\
50.9 \\
40.2 \\
29.9 \\
24.9 \\
26.7 \\
23.5 \\
18.4 \\
13.2 \\
11.9 \\
8.5 \\
8.6 \\
5.7 \\
5.3\end{array}$ & $\begin{array}{l}104.1 \\
51.3 \\
47.1 \\
41.5 \\
39.4 \\
52.0 \\
45.9 \\
42.2 \\
31.3 \\
21.3 \\
15.6 \\
15.2 \\
11.8 \\
10.3\end{array}$ & $\begin{array}{r}3.7 \\
23.7 \\
25.3 \\
24.6 \\
12.7 \\
18.0 \\
24.3 \\
16.2 \\
17.3 \\
23.1 \\
32.8 \\
33.1 \\
43.2 \\
47.5\end{array}$ & $\begin{array}{r}-0.018 \\
0.099 \\
0.164 \\
0.243 \\
0.326 \\
0.298 \\
0.316 \\
0.356 \\
0.266 \\
0.205 \\
0.212 \\
0.181 \\
0.217 \\
0.130\end{array}$ & $\begin{array}{c}0.0075 \\
0.0307 \\
0.0285 \\
0.0175 \\
-0.0012 \\
0.006 \\
0.0240 \\
0.0176 \\
0.0220 \\
0.0321 \\
0.0374 \\
0.0461 \\
0.0506 \\
0.0581\end{array}$ \\
\hline
\end{tabular}

$m=[\partial \log \sigma / \partial \log \varepsilon] \dot{\varepsilon}, T . n=[\partial \log \sigma / \partial \log \varepsilon] \dot{\varepsilon}, T$ $\sigma:$ 応力, $\varepsilon:$ 坐, $\dot{\varepsilon}:$ 麥速度, $T:$ 温度

(56) W.Dürrschnabel: Z. Metallk., 53(1962),775.
Mordike(54) は $1550^{\circ} \mathrm{C}$ および $1980^{\circ} \mathrm{C}$ での高温引張り 試験を行ない，各々 $4.99 \mathrm{~kg} / \mathrm{mm}^{2}$ 打よび $3.59 \mathrm{~kg} / \mathrm{mm} 2$ の值を得た。これらの值は $\mathrm{Nb}$ のほ注倍である。 歪速度は Ta の全伸び量にはほとんど影響しない が引張り強さ，降伏值などには大さな影響を与え $る^{(52)(55) \sim(57) .}$

中性子照射によつて導入される空孔のため引 張り強さは 10 数 \%上昇し, 硬度の增加がみられ た(58).

延性対脆性遷移温度は常温から $-196^{\circ} \mathrm{C}$ の範团 内ではみとめられなかつた (52)(55)(59). 電子ビーム 溶解材の遷移温度は $-250^{\circ} \mathrm{C}$ 以下(60) といわれて 抢り，他の体心立方金属比比べて低温まで勒性に 富む．遷移温度は普通衝撃試験結果から求められ るが，Ta 中の○によつてはあまり影響されず， $760 \mathrm{ppm}$ の0を含む加工材の場合その遷移温度は -196 ${ }^{\circ} \mathrm{C}$ 以下であつた(61).

水素による脆性 ${ }^{(62)}$ は $\mathrm{Fe}$ や V の場合と似てい るが, Hの固溶度が温度とともに急激に变化し， 水素化合物を形成するので, その脆性挙動は現在 まだ明白ではない，低温脆性破面は $\{110\}$ または $\{100\}$ であつた(42).

電子ビーム溶解材のクリープ 特性は Holden ら (48)(51) によつて研究され，第 9 図にその結果を示すが，クリー プ曲線は温度の上昇にともなう時間的依存性を明らかに 示している.

Allen ら ${ }^{(63)}$ は $24 \mathrm{hr}$ で $1 \%$ の変形を与克る压縮クリー プ試験を行ない, $1000^{\circ} \mathrm{C} て ゙ ~ 4.72 〜 6.30 \mathrm{~kg} / \mathrm{mm}^{2}$ のクリ 一プ強度を求め, 試験中 $30 \mathrm{VHN}$ の試片の硬化をみとめ ている．素材中に含まれる侵入型不純物元素は第 2 表か らも明らかなようにクリープ強度の增加をもたらす。

再結晶した Ta の板や線の常温に 淤膺労限 $(2 \times$ 107 サイクル)はほぼ引張り強さの $60 \%$ である。低温で は疲労限自体は上昇するが, 引張り強さとの比はかえつ て減少し $-73^{\circ} \mathrm{C}$ では $50 \%$ 前後になる・水素を含む場合 は疲労強度の低下がみとめられ， S-N曲線の折れ (knee)

(57) A.L.Mincher and W.F.Sheerly: Trans.AIME, $221(1961), 19$.

(58) D.O.Leesser: Materials and Methods, 40 (1954), 109.

(59) E.T.Wessel: J.Metals, 9 (1957), 930.

(60) A.G.Imgram, F.C.Holden, H.R.Ogden and R. I.Jaffee: Battelle Memorial Inst., WADD-TR60-278 (Apr.1960) .

(61) A.G. Imgram, E.S. Bartlett and H.R. Ogden: Trans.AIME, $230(1964), 928$.

(62) A.G. Imgram, E.S. Bartlett and H.R. Ogden: Trans.AIME, 227 (1963), 131.

(63) N. P. Allen and W. E. Carrington: J. Inst. Metals, $82(1953 \sim 54), 525$. 

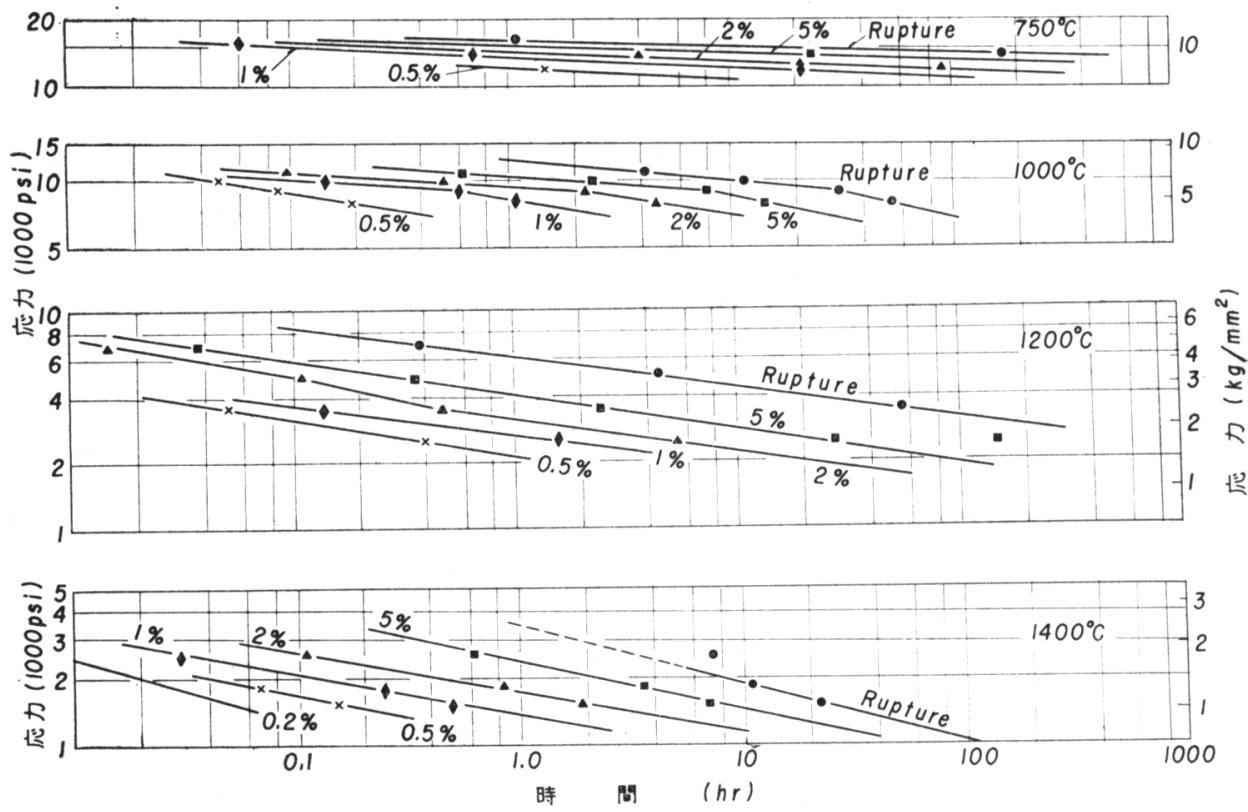

第 9 図高純度タンタルのクリープ曲線(1)

Mo, Hf, Re, V,W, Os, Ru な どの添加元素は, Ta の再結晶 温度や硬度を高め, $20 \%$ 前後ま での添加は高温強度のみならず 常温強度も増大させる(2)(29)(48). たと党ば Ta-20\% W 合金の再 結晶温度は $1600^{\circ} \mathrm{C}$ で, その高 温引張り強さは Taの 4 倍に達 する。しかし V,Hf, Ti, Zr など の多量添加はかえつて高温強度 を低下させる・たとえば Ta-40 \% Ti 合金は高温強度を Taの $1 / 3$, その再結晶温度を $1000^{\circ} \mathrm{C}$ 前後に低下させる.

3 元合金では種々の合金が開 発されているが, 室温に打壮る 加工性や高温強度などの点から Ta-10\% Hf-5\% W 合金などが 優れている。これら $\mathrm{Ta}$ 基合金 の室温ならびに $1200^{\circ} \mathrm{C}$ 高温強 度を第 10 図に示す。

さらに有効添加元素としてCがあり，Ta-10\% Hf-5\% $\mathrm{W}$ の再結晶温度を $540 \mathrm{ppm}$ の C の添加で $100^{\circ} \mathrm{C}$ 高め,

(64) B.A.Wilcox: Trans, AIME, 230 (1964), 1199.

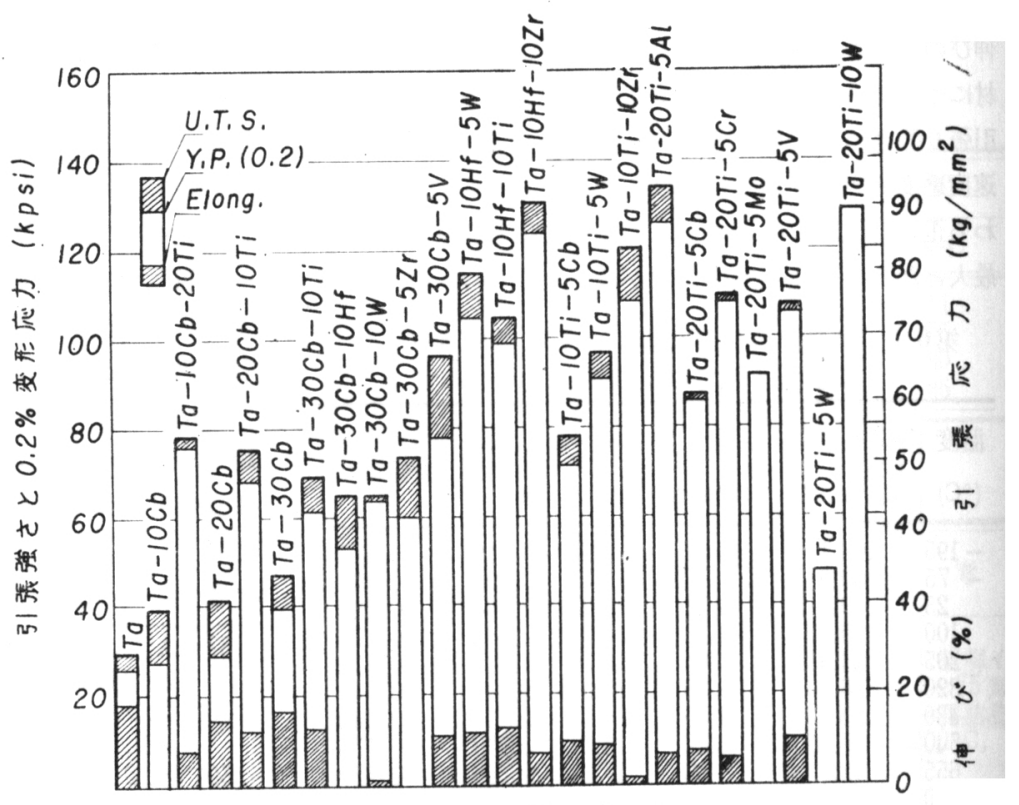

（）常 温引張 強さ

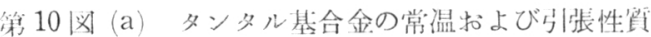

U.T.S.：引張強已, Elong：伸び, Y.S.：降伏強さ
る。また用途上強度/比重が大きいほど, その耐熱材料 適性はよいといらことが壮米る。第11 図に種々の们熱 材料の高温强度/比重と温度の関係(29) 索図示した。この 
図から明らかなように $1400^{\circ} \mathrm{C}$ 以下では，比重の小さい $\mathrm{HCl}$ では $1 / 1000$ in/year 以下の浸食に過ぎないが， $30 ，$ $\mathrm{Nb}$ 合金 (F-48) や Mo (TZM) が優れている。したがっ $37 \%$ と濃度が上年するにしたがつて浸食量もそれぞれ て Ta の場合は, $1400^{\circ} \mathrm{C}$ 以上での使用目的 に優れる耐熱合金の開発を目的としなければ ならない。

すでに実用化されている Ta-10\%W 合金 や開発途上の Ta-10 Hf-5 W 合金は十分他種 の合金と比眉し5るのみならず, 現在研究進 行中の多種多様の $\mathrm{Ta}$ 基合金の研究結果から 将来 $1400^{\circ} \mathrm{C}$ 以上での 而熱合金が生れること はほぽ間違いないと考光られている(2)(29).

\section{Ta の化学的性質}

\section{(1) Ta の耐食性}

Ta は各種の化学薬品に対し極めて安定で あつて，第7 表に示すように $150^{\circ} \mathrm{C}$ 以下では ほと儿ど侵されることがない、たた゚し $\mathrm{HF}$ ， $\mathrm{SO}_{3}$ 拈よび濃厚なアルカリには侵される。一 般的にいえばむしろ $\mathrm{Nb}$ よりも耐食性が優れ ているといらことが出来る.

塩酸: $110^{\circ} \mathrm{C}$ までは濃度に関係なく安定で ある.たとえば $\mathrm{HCl}$ の加熱のための投げ込 みヒーターの鞘として作った $0.3 \mathrm{~mm}$ の厚み

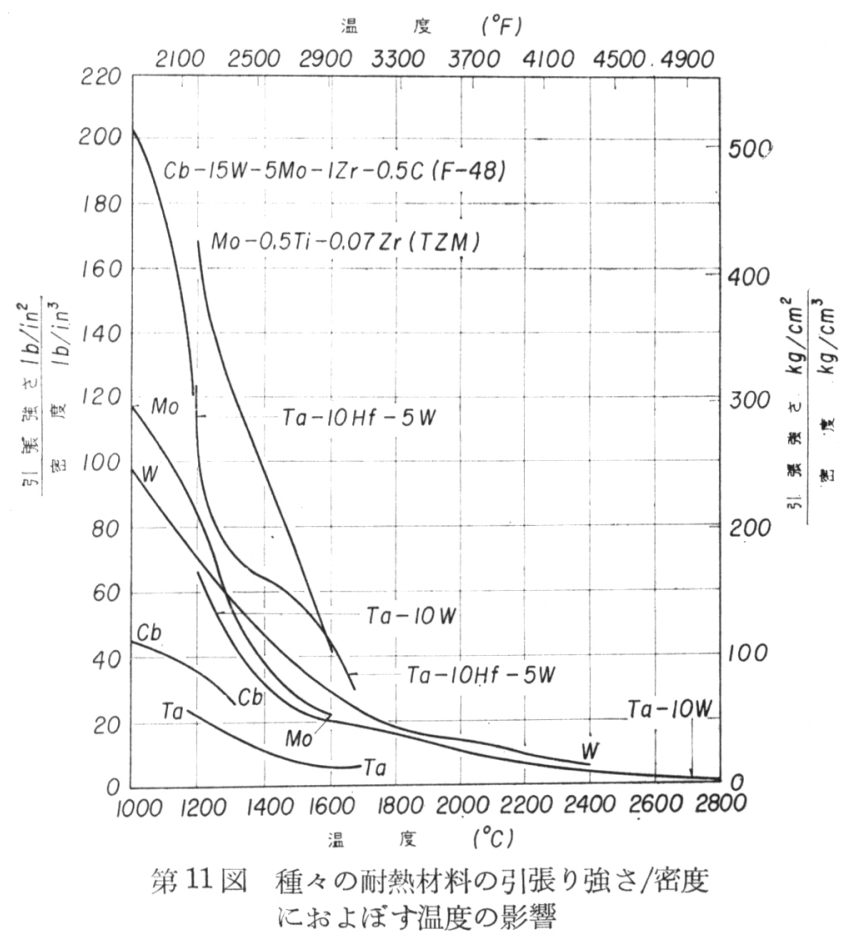

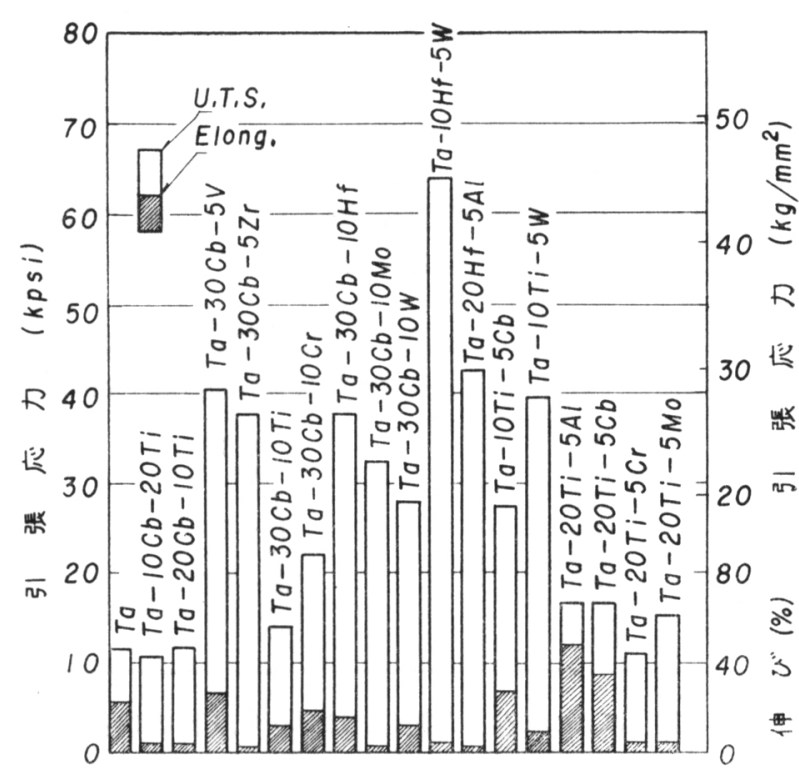

(b) $1200^{\circ} \mathrm{C}$ における引張强さ 第10 図(b) タンタル基合金の $1200^{\circ} \mathrm{C}$ の引張り性貿 U.T.S.：引張強さ, Elong：伸び, Y.S.：降伏強さ
$3.9 / 1000,11.6 / 1000$ in/year となるが(66)，な招 極めて安定な材料ということが出来る.

硝酸：硝酸に対してはほとんどあらゆる条件で 安定で, 発煙硝酸打よび塩酸や塩化物の共存する 場合にも問題なく使用汇耐える.

硫酸： $175^{\circ} \mathrm{C}, 98 \% \mathrm{H}_{2} \mathrm{SO}_{4}$ 上り以上の 条件では 徐々に腐食するが, これ以下の温度, 濃度では侵

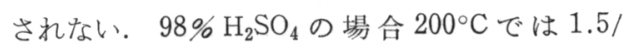
1000 (in/year), $250^{\circ} \mathrm{C}$ で $29 / 1000,300^{\circ} \mathrm{C}$ で $342 /$ 1000 である(1) が, $\mathrm{H}_{2} \mathrm{SO}_{4}$ の濃度が低くなれば腐 食量は減少し, $90 \% \mathrm{H}_{2} \mathrm{SO}_{4}$ では同じ温度条件の $98 \% \mathrm{H}_{2} \mathrm{SO}_{4}$ の約 $1 / 10$ である(67) な括沸騰 $\mathrm{H}_{2} \mathrm{SO}_{4}$ 中では水素脆性を起寸危険がある, 発煙硫酸に対

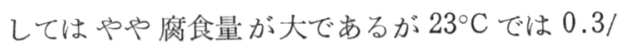
$1000,50^{\circ} \mathrm{C} て ゙ 4 / 1000$ と安定しているが $70^{\circ} \mathrm{C} て ゙$

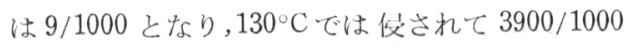
(単位は in/year) となる。

りん酸： $180^{\circ} \mathrm{C}$ までは安定であるが， $250^{\circ} \mathrm{C} に$ なれば 20/1000 in/year の腐食量を示す. 以上の のパイプが 20 年以上も使われた例がある. $190^{\circ} \mathrm{C}, 25 \%$

(65) Fansteel Metal. Corp. The Metal Tantalum (1953).
ように各種の酸に対してはかなり安定であるが，濃厚な

(66) F.S.Badger: Ind. Eng.Chem., 50 (1958), 1608.

(67) C.A.Hampel: Corrosion, 14(1958), 557. 
アルカリ溶液に対しては室温でも徐々に溶解する。これ は Ta の酸化物が酸性であるため, タンタル酸ソーダー 第 7 表 $\mathrm{Ta}$ の酸による腐战

\begin{tabular}{|c|c|c|c|}
\hline 酸 & ${ }^{\left.\text {温 }{ }^{\circ} \mathrm{C}\right)}$ & $\begin{array}{l}\text { 試 験 } \\
\text { 日数 } \\
(\text { (日) }\end{array}$ & $\stackrel{\text { 重 }}{\left.\text { (g/ } / \mathrm{dm}^{2} / \text { day }\right)}$ \\
\hline $\mathrm{HCl}$, Conc. & $19 \sim 26$ & 135 & 0.0000 \\
\hline " & 110 & 5 & 0.0000 \\
\hline $\mathrm{HNO}_{3}$, Conc. & ${ }_{86}^{19} 26$ & 135 & 0.0000 \\
\hline $\mathrm{HNO}_{3} \cdot \mathrm{HCl}$, 水溶液 & 24 & - & 0.0000 \\
\hline $\mathrm{H}_{2} \mathrm{SO}^{\prime \prime}$ Conc. & $\begin{array}{c}54 \\
19 \sim 26\end{array}$ & 135 & $\begin{array}{l}0.0000 \\
0.0000\end{array}$ \\
\hline & 147 & $\begin{array}{r}100 \\
90\end{array}$ & 0.00004 \\
\hline "I & 175 & 30 & 0.0014 \\
\hline "I & 200 & 30 & 0.0177 \\
\hline " & 250 & $1 / 4$ & 0.332 \\
\hline & 300 & $1 / 8$ & 3.96 \\
\hline $\mathrm{H}_{2} \mathrm{SO}_{4}$, Conc. $+\mathrm{K}_{2} \mathrm{Cr}_{2} \mathrm{O}_{7}$ & $19 \sim 26$ & 135 & 0.0000 \\
\hline " & 96 & 90 & 0.00004 \\
\hline $\mathrm{CrO}_{3} \times ッ キ$ 浴 & 98 & 90 & 0.00002 \\
\hline $\mathrm{H}_{3} \mathrm{PO}_{4}, 85 \%$ & $\begin{array}{c}145 \\
180 \sim 210\end{array}$ & $\begin{array}{l}90 \\
31\end{array}$ & $\begin{array}{l}0.00005 \\
0.0027\end{array}$ \\
\hline 発煙 $\mathrm{H}_{2} \mathrm{SO}_{4}, 15 \% \mathrm{SO}_{3}$ & 23 & $1 / 12$ & 0.0032 \\
\hline " & 70 & $1 / 4$ & 1.06 \\
\hline & 130 & $1 / 12$ & 45.6 \\
\hline 蓚酸・飽和溶液 & 96 & 90 & 0.0001 \\
\hline $\mathrm{FeCl}_{3}, 10 \%$ & 24 & - & 0.0000 \\
\hline $\mathrm{FeCl}_{3}$, Conc. & 24 & - & 0.0000 \\
\hline
\end{tabular}

を作るからである。

八ロゲン: $\mathrm{Cl}, \mathrm{Br}, \mathrm{I}$ には $150^{\circ} \mathrm{C}$ まで安定であるが， F には室温に括いても腐食される。 $\mathrm{Cl}$ は $250^{\circ} \mathrm{C}$ 上り, $\mathrm{Br}$ とIは約 $300^{\circ} \mathrm{C}$ 以上でTaを侵すようになる。Ta- $18 \%$ $\mathrm{W}$ 合金は耐酸性に優れ，20\% HF 飞対しても安定であ る.

液体金属： $\mathrm{Na}$ や $\mathrm{Na}-\mathrm{K}$ に対しては $1000^{\circ} \mathrm{C}$ まで安定

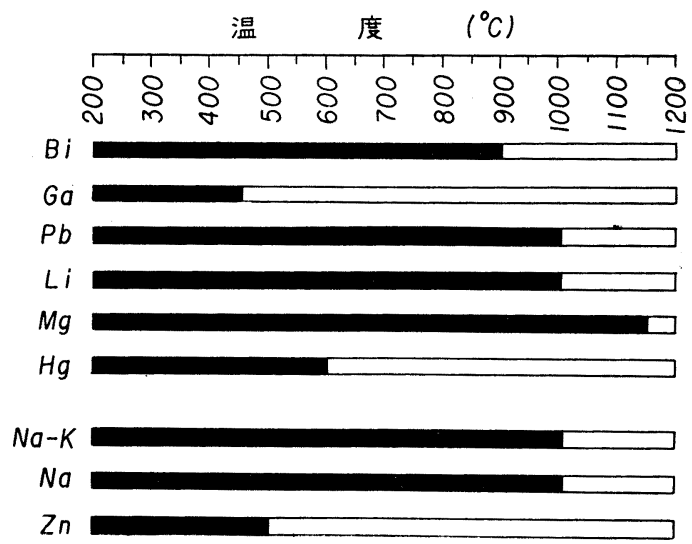

一酎食性良好 $\square$ 耐食性がそしい 第 12 図 Ta の溶融金属に対する耐食性

であり，その他の液体金属に対しても第 12 図(2) に示す ようで $450^{\circ} \mathrm{C}$ 以下では非常によい耐食性をもつている.

\section{(2) 電気化学的挙動}

Ta と水が反応して酸化物を作る際の平衡電位は次式 によって与えられている(2).

$$
\begin{aligned}
2 \mathrm{Ta}+5 \mathrm{H}_{2} \mathrm{O} & =\mathrm{Ta}_{2} \mathrm{O}_{5}+10 \mathrm{H}^{+}+10 \mathrm{e} \\
E & =-0.750-0.059 \mathrm{pH}
\end{aligned}
$$

$\mathrm{Ta}$ の腾れた耐食性は表面に $\mathrm{Ta}_{2} \mathrm{O}_{5}$ の緻密な保護性被膜 が出来るからである。この $\mathrm{Ta}_{2} \mathrm{O}_{5}$ は整流作用をるちタ ンタルコンデンサーとして重要なものである. Ta と他 の金属とを組み合わせた電気化学的回路を作ると Taは 常に陰極となる。この極性は時間の影響を受け，1 min 以内の時と約 $1 \mathrm{hr}$ 後では逆になることもあるが(2)，Ta が陰極として働くため, 水溶液中で発生した水素が $\mathrm{Ta}$ 中江叹されて水素化合物を作り，水素脆性の原因とな ることがあるため，化学工業用材料として使用するとき は注意しなければならない。

\section{(3) Ta とガスとの反応}

$\mathrm{Ta}$ は大気中で $260^{\circ} \mathrm{C}$ 以下では数時間の加熱を行なつ ても表面の色調が変化するに過ぎないが, それ以上の温 度では酸化が進行し， $400^{\circ} \mathrm{C}$ 付近より顕著になり，500 ${ }^{\circ} \mathrm{C}$ に加熱すれば表面に白色の酸化物 $\left(\mathrm{Ta}_{2} \mathrm{O}_{5}\right)$ が認めら れるようになる． $220^{\circ} \sim 320^{\circ} \mathrm{C}$ までの低温度では Taの 空気酸化は対数的に重量增加を示し ${ }^{(68)}$, その活性化工 ネルギは $12,000 \mathrm{cal} / \mathrm{mol}$ である. $320^{\circ} \sim 500^{\circ} \mathrm{C}$ の範囲で は扰物線的に酸化增量が進行 ${ }^{69)}$ 乙, 活性化エネルギは $27,200 \mathrm{cal} / \mathrm{mol}$ である. さらに高温度 $\left(600^{\circ} \sim 900^{\circ} \mathrm{C}\right)$ 以 上では直線的に酸化が進行する(70).

$\mathrm{Ta}$ と酸素： $300^{\circ} \mathrm{C}$ 以下では対数法則にしたがうが, $450^{\circ} \mathrm{C}$ 以上では酸化被膜は保護性を失い直線的に重量增 加を示すようになり，第 8 表(71) に示すようである.

\begin{tabular}{|c|c|c|}
\hline 温 & 度 $\left({ }^{\circ} \mathrm{C}\right)$ & 酸化速度恒数 (直線的) $\mathrm{mg} / \mathrm{cm}^{2} / \mathrm{hr}$ \\
\hline & $\begin{array}{r}500 \\
600 \\
700 \\
800 \\
900 \\
1000 \\
1100 \\
1200\end{array}$ & $\begin{array}{l}0.33 \\
9.2 \\
17 \\
13 \sim 15 \\
48 \\
139 \sim 140 \\
165 \\
227\end{array}$ \\
\hline
\end{tabular}

\section{第 8 表 $\mathrm{Ta}$ と 1 気圧の酸素の反応}

酸化によつて生じた酸化物は $450^{\circ} \mathrm{C}$ 以下では青褐色で あるが、高温になるにしたがつて黄色ないし白色となり，

(68) J.T.Waber et al: J.Electrochem.Soc.,99(1952), 121.

(69) E. A. Gulbransen and K. F. Andrew: Trans. AIME, 188(1950), 586 .

(70) F.F.Schmidt: DMIC Rept., 133(1960),133.

(71) F. F. Schmidt et al : WADD TR No. 59-13, (1959) . 
これは $\mathrm{Ta}_{2} \mathrm{O}_{5}$ である.酸化物は $\mathrm{Ta}$ の (100) 面に添つて 成長し浸透して行く(72).

第 9 表 $\mathrm{Ta}$ と窒菜の反必

\begin{tabular}{|c|c|c|}
\hline$\frac{\text { 温度 }}{\left({ }^{\circ} \mathrm{C}\right)}$ & $\begin{array}{c}\text { 反応速度恒数抛物線則 } \\
\left(\mathrm{mg} / \mathrm{cm}^{2}\right)^{2} / \mathrm{hr}\end{array}$ & 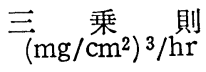 \\
\hline $\begin{array}{r}400 \\
600 \\
700 \\
800 \\
900 \\
1000 \\
1100 \\
1200 \\
1300\end{array}$ & $\begin{array}{c}\text { 二 } \\
\overline{-} \\
7.2 \sim 8.0 \times 10^{-4} \\
9.5 \times 10^{-3} \\
3.9 \times 10^{-2} \\
1.4 \times 10^{-1} \\
7.1 \times 10^{-1} \\
2.6\end{array}$ & $\begin{array}{c}2.6 \times 10^{-7} \\
4.3 \sim 5.3 \times 10^{-7} \\
4.4 \sim 7.3 \times 10^{-7} \\
- \\
- \\
- \\
- \\
-\end{array}$ \\
\hline
\end{tabular}

$\mathrm{Ta}$ と窒素: $800^{\circ} \sim 600^{\circ} \mathrm{C}$ 以上では抛物線則にしたが らが，この温度以下では 3 乗則にしたがい第 9 表に示す ようである.

Ta と水素：タンタルの水素吸収は温度上昇とともに 減少し, 圧力の平方根に比例していることから Ta 中の Hは原子の状態で入つていることが理解される. Ta と $\mathrm{H}_{2}$ との反応山 金属の表面状態に左右され, 真空脱ガス を行なつたり新らしく切削加工を受けた面は若干の酸化 を受けた Taよりはるかに早い速度で水素吸収を示す。

$\mathrm{Ta}$ 中のH の拡散は非常に早いので 表面化化合物を作ら ず，浸入型不純分としてTa 格子内に固溶する．したが ってH吸収により格子常数は大となり, 引張り強さ, 耐 力, 伸びなどが減少し脆くなり, 硬さおよび電気抵抗は 大となる.

\section{(4) Taの仕上げ,その他}

酸洗い: 熱塩酸, 王水, およびクロム硫酸などで洗つ たのち十分水洗いして乾燥する.

エッチング：Ta 拉よび Ta 合金の 顕微鏡検査のため の腐食液として第 10 表の組成の混酸が用いられている. な招 Ta の研摩は水またはケロシンを潤滑剤として用 い,エメリー紙打よびバフによつて通常の軟い金属に準 じて行なう。殊に純金属は軟いので荒仕:上げの条跡に注 意が必要である.

電解研摩：純 $\mathrm{Ta}$ は $\mathrm{Nb}$ とほぼ同様につぎの電解液を 用いて顕微鏡試料の電解研摩を行ならことが出来る.

(a) $\mathrm{HNO}_{3} 170 \mathrm{~mL}+\mathrm{HF} 50 \mathrm{~mL}+\mathrm{NH}_{4} \mathrm{~F} 30 \mathrm{~g}+$ メタ ノール $510 \mathrm{~mL}$; 電流密度 $3.5 \mathrm{~A} / \mathrm{cm}^{2}, 40 \sim 120 \mathrm{sec}$ 電 解したのち 2 3 min 電流を切つて处理を行なう. (b) $\mathrm{H}_{2} \mathrm{SO}_{4} 90 \mathrm{~mL}+\mathrm{HF} 10 \mathrm{~mL}$; 電压 $1.5 \mathrm{~V}$ で $3 \sim 10 \mathrm{sec}$, (c) $\mathrm{CrO}_{3} 16 \mathrm{~g}+\mathrm{HF} 16 \mathrm{~mL}+\mathrm{H}_{2} \mathrm{SO}_{4} 40 \mathrm{~mL}+\mathrm{H}_{2} \mathrm{O} 40 \mathrm{~mL}$; 電圧 $6 \mathrm{~V}$ で 10〜30 sec の電解を行なう. 試料は白金線などで 保持して陽極とし院極には白金または黒鉛を用いる。電 解研摩はかなり微妙な技術を要し, 電解液は槽の条件な

(72) R.Bakish: J.Electrochem.Soc., 105 (1958) ,71.
ぞにより若千の調節が必要で, 硫酸はエッチピットの発 生の防止効果があり, また水は研摩作用と腐食作用の均 第 10 表 $\mathrm{Ta}$ 抢よび Ta 合金の腐食液(2)

\begin{tabular}{|c|c|c|}
\hline 腐 液 食 & 途 & 備 \\
\hline 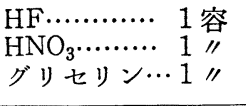 & $\begin{array}{l}\mathrm{Ta}, \mathrm{Nb} \text { および } \\
\text { これら合金一般 }\end{array}$ & $\begin{array}{l}\text { 綿を用いて表 } \\
\text { 面を拭う。 }\end{array}$ \\
\hline 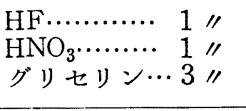 & $\mathrm{Ta}-\mathrm{V}$ 合金 & $\begin{array}{l}\text { 試料を浸漬す } \\
\text { る. }\end{array}$ \\
\hline 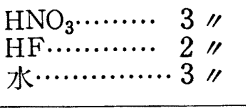 & $\mathrm{Ta} \sim \mathrm{TaC}$ 系 & " \\
\hline 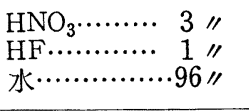 & $\mathrm{Ta}-\mathrm{Ti}$ 合金 & "I \\
\hline $\begin{array}{l}\mathrm{HNO}_{3} \ldots \ldots \ldots .96 " \\
\mathrm{HF} \ldots \ldots \ldots .3 \sim 5 "\end{array}$ & $\begin{array}{l}\text { Ta-Mo 合金, } \\
\text { Ta-貴金属采 }\end{array}$ & "I \\
\hline 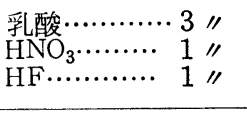 & $\begin{array}{l}\text { Ta 执よび Ta } \\
\text { 合金の化学研摩 } \\
\text { 溶ともなる. }\end{array}$ & $\begin{array}{l}5 \mathrm{sec} \text { 間隔で } \\
\text { 断続的に行な } \\
5 .\end{array}$ \\
\hline $\begin{array}{l}\mathrm{H}_{2} \mathrm{SO}_{4} \cdots \cdots \cdots \cdot 1 " \\
\mathrm{HF} \cdots \cdots \cdots \cdots \cdot 1 "\end{array}$ & $\begin{array}{l}\text { 化学研摩後に用 } \\
\text { いる Ta および } \\
\text { Ta 合金 }\end{array}$ & $\begin{array}{l}\text { 白金線で支え } \\
\text { た試料を陽極 } \\
\text { 黒鉛電極を陰 } \\
\text { 極として電解 } \\
\text { エッを行な } \\
5.1 \text { V Vで } \\
\text { 約 } 2 \text { min 間 }\end{array}$ \\
\hline 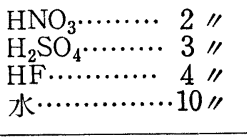 & Ta 全般 & 浸漬する。 \\
\hline 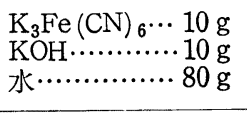 & Ta-Mo 合金 & " \\
\hline 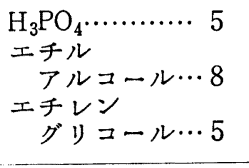 & Ta-U 系 & 浸漬する. \\
\hline $\begin{array}{lll}\mathrm{H}_{3} \mathrm{PO}_{4} \ldots \cdots \cdots \cdots \cdots \cdots & 5 \\
\mathrm{HNO}_{3} \cdots \cdots \cdots \cdots \cdots & 1 \\
\mathrm{HF} \cdots \cdots \cdots \cdots \cdots \cdots & 4\end{array}$ & $\mathrm{Ta}$ 基合金 & " \\
\hline 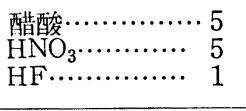 & $\begin{array}{l}\text { Ta 合金でュア } \\
\text { 一の出る場合に } \\
\text { 用いる. }\end{array}$ & "I \\
\hline $\begin{array}{ll}\mathrm{HC} 1 \ldots \ldots \ldots \ldots \cdots \cdots & 2 \\
\mathrm{HNO}_{3} \cdots \cdots \cdots \cdots \cdots & 1 \\
\mathrm{HF} \ldots \cdots \cdots \cdots \cdots \cdots & 2\end{array}$ & $\mathrm{Ta}$ 合金 & 銹発生に注意 \\
\hline
\end{tabular}

衡を保つ上に重要な役割をしている，使用にさきだち若 干時間の予備電解を行なつて浴中に Ta イオンを与える と好結果が得られる.

9. 用

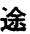


Ta の用途は大別して電子工業用，耐食材料扣よび耐 熟材料とすることができる。が园では約 $80 \%$ が電子 エ、業に用いられている。

タンタルコンデンサーを模型的に亦すと第13図の ようで, Тa 粉木を成型, 適当な焼結を行なつたのち,

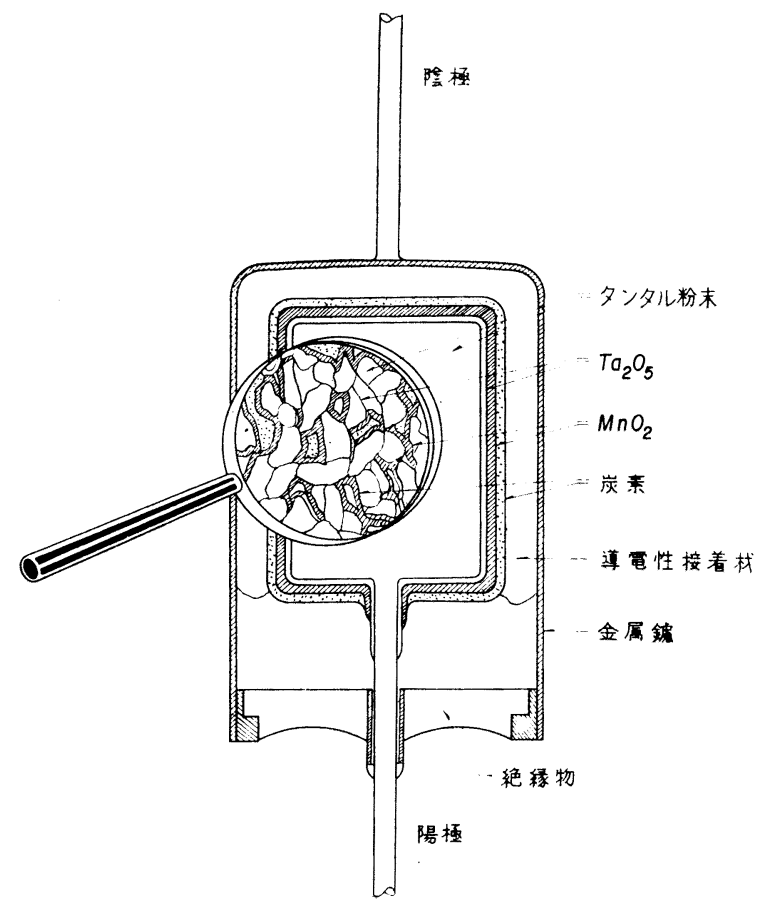

第 13 図 $\mathrm{Ta}$ コンデンサ一模型図(2)

$\mathrm{Ta}_{2} \mathrm{O}_{5}$ の酸化被慕を作り, 順次 $\mathrm{MnO}_{2}\left(\mathrm{Mn}\left(\mathrm{NO}_{3}\right)_{2}\right.$ を含没 させて加熱生成する)，Cで充填し觹に收める。他の種 類のコンデンサーに比べ単位体積当り最大の静電容量を 持つているので極めて小型化することが出来, トランジ スター回路には不可欠のものである。使用温度範囲も公 く $-80^{\circ} \mathrm{C}$ から $180^{\circ} \mathrm{C}$ にわたつて漏洩も少なく安定で, から寿命も長いなど優れた特性を示す.

真空管材料としてはつぎのような長所がある。すなわ ち融点が高いので高い出力による高温使用に耐えるとと もに, 蒸気圧が低く脱ガス処理を十分に行なえば非常に 安定な材料である. 製造加工の面からも薄板や線などの 複雑な形状のものを作ることが容易で, 鞁性, 強度も十 分でありさらにダッター作用も侀せ持つている。高温具

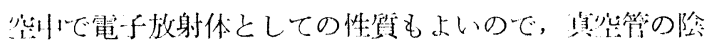
䡒としても崩られる。

$\mathrm{W}$ に $7.5 \% \mathrm{Ta}$ を添加した線は高温度で弾性を失なわ ないので真空管球フィラメント，スプリングとして使用 され，Ni 汇 $30 \%$ までの Taを加えた合余惊球材料と して使われている。
化学工業耐食設備としては Ta は極めて優れている。 州酸, $\mathrm{SO}_{3}$ などの例外を际注ば Taは酸に対して全く侵 されないということができる。嘰峨的強度もかなり高く

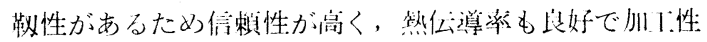
も具えているため, 溥闪管を使つた熱交換器, 冷却コイ ル，凝縮機など重要部分に賞用されている，従来薄板の 溶授加工に当り, 父泡発生の欠侯があつたが, 電子ビー 么溶解材之溶援施上技術の進少によつて複雑な形状の製 尚が造られるよらになつたのでさらに治い用途が開発さ れるであろう。

的酸高生容器の内弦りなどの他, グラスライニング容 器の補修にも第 14 図のような Ta 枪志心用することが 计米弓。

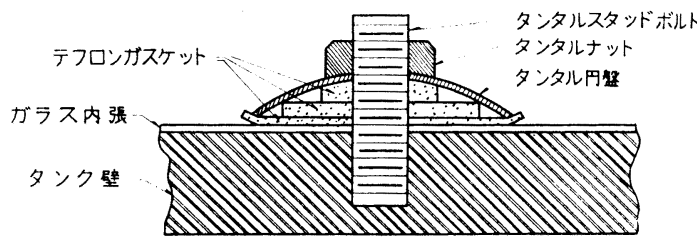

第 14 図 グラスライニング容器の補修用 Ta プラグ

高温䓡処理炉用発熱体として真空またはAr中で用い られる。融点が高いため約 $2300^{\circ} \sim 2400^{\circ} \mathrm{C}$ まで使うこ とができる. 真空炉の発熱体としては寿命が長いので経 済的である。これは $2000^{\circ} \mathrm{C}$ 以上の真空中では吸着ガス の離脱の他 $\mathrm{C}$ と $\mathrm{O}$ の反応や $\mathrm{TaO}$ の蒸発など $\mathrm{Ta}$ 自体の 精製効果が起り，常に高純度が保たれるためで，Moゃ Wなどに見られる高温使用の後の脆化がなく勒性を保つ ため, 工業的取り投いが容易である。

医療用として Ta の応用は最近注目されるようになつ た. Taは人体に対して全く無害であるとともに，無刺 激性であるため, 外科手術用の補強, 補修忉料として, 殊飞頭の骨折の際の補強金具材料，神経系統の外科治㙩 材料, 縫い目用の針金など, 広く金や白金などの貴金属 に代つて用いられつつある。

その他, 将来の用途として原子炉構造材料としても考 えられている。現在の原子少では熱中性子経済のために 吸收断面積の大きい忉料は为芯部に使用されないが，将 米開発される計画の高速增殖炉ではこの制限が緩和され るので，高波度の泠却剂である液休 $\mathrm{Na}$ や $\mathrm{Na}-\mathrm{K}$ に耐食

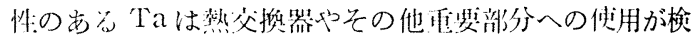
沽されていら。

以上 Taの特性を紿介したが，他の金属には見られな い耐食性，耐熱性を基にし，新らしい Ta 合金の開発に 伴なつてますますとの有用性が認められ，輝かしい前途 が約東されている。 